\title{
Source-to-Sink analysis of the Plio-Pleistocene deposits in the Suez rift (Egypt)
}

Rohais Sébastien $\left(1,{ }^{*}\right)$

Rouby Delphine (2)

(1) IFPEN, Direction Géosciences, 1 et 4 Avenue de Bois-Préau, 92852 Rueil-Malmaison Cedex. France

(2) Géosciences Environnement Toulouse, Université de Toulouse, CNRS, IRD, UPS, CNES, F31400, France

*e-mail address of corresponding author: sebastien.rohais@ifpen.fr

Keywords: Suez rift, syn-rift, post-rift, catchment, sediment supply, source-to-sink, Pliocene, Pleistocene

\section{Abstract}

We present a source-to-sink (S2S) study of the Plio-Pleistocene deposits in the Suez rift (Egypt). We used stratigraphic record and quantitative geomorphology to constrain relief evolution in a rift setting from a high-resolution database at basin-scale $(\sim 300 \mathrm{~km} \times 100 \mathrm{~km})$ including, digital elevation model, outcrop and subsurface data. The stratigraphic architecture shows five main stages ranging from rift initiation to tectonic quiescence (Oligo-Miocene) plus a post-rift stage (PlioPleistocene). We quantified sediment accumulation history and analysed the relationship between catchment and sediment supply for the Plio-Pleistocene (post-rift stage). The results of the source-tosink study for the post-rift stage were then compared to previous estimations for the main rifting stages.

We show that the sediment supply dynamics of the Plio-Pleistocene deposits of the Suez rift records a renewed uplift ca. 5 Myr ago. However, we also show that a major climate shift related to the Pliocene revolution was most probably coeval to reach the magnitude of accumulation observed. 


\section{Introduction}

Source-to-sink (S2S) approaches integrate the domains in erosion, transport and deposition of sediment routing systems as a single dynamically linked system. These approaches are fundamental to understand the controls of each of the three sub-systems and their feedbacks (e.g. Einsele et al. 1996; Allen 2008; Sømme et al. 2009; Pechlivanidou et al. 2017). However gathering the data necessary to constrain the three domains for a single sedimentary system can be very challenging as it requires the characterization of the entire sedimentary basin that is to say isopach and paleogeographic maps, timelines calibrated in absolute ages, timing of deformation and, ideally, constraints on evolution of reliefs and drainage systems through time. These data allow for the quantification of the sedimentary budget of the basin, that have been implemented in various types of basins (e.g. Einsele et al. 1996; Rouby et al. 2009; Guillocheau et al. 2012). Paleo-relief and erosion dynamic models have also been successfully applied (Kennan et al. 1997; Babault et al. 2005; Barnes and Heins 2009). Nevertheless, as ancient reliefs and drainage systems are not usually preserved, their characterization remains very challenging at geological time scales. The joint characterization of the catchments and the deposits resulting from their erosion is more often possible for the presentday systems (e.g. Styvisky et al. 2003; Eide et al. 2017). Using these relationships and the associated sedimentary budget, we can somewhat infer the dynamic of erosion and paleo-reliefs. Nevertheless, the down-system grain size fining is usually poorly known and still limits the determination of the proper relationship between sediment supply and erosional processes in the catchments (Whittaker et al. 2010; Hampson et al. 2014). Consequently, breakthroughs in source-to-sink approaches of sediment routing systems can only happen once the three domains, erosion, transport and deposition are well characterized at basin-scale.

Well-constrained S2S case study are extremely rare but the Suez rift is a good candidate because it is a "closed system" where the material eroded in the catchments has been entirely 
trapped in the sedimentary basin. We expanded the detailed database established by Rohais et al. (2016) for the Plio-Pleistocene to characterize the evolution of the sediment routing system since the Miocene. The description of the sediment supply dynamic and high-resolution accumulation history at basin-scale have been used to discuss the associated paleo-reliefs evolution.

\section{The Suez rift}

The Suez rift is the NW-SE-trending branch of the Red Sea rift system (Fig. 1), resulting from the late Oligocene to early Miocene rifting of the African and Arabian plates (Garfunkel and Bartov 1977). It is bounded by large-scale normal fault zones (ca. $40-80 \mathrm{~km}$ long and ca. 2-6 km offset, Fig. 1b). The polarity of the major faults varies along the rift axis, dividing the rift into three $50-100 \mathrm{~km}$ long sub-basins (Colletta et al. 1988; Patton et al. 1994; Moustafa 1996): (i) the northern Darag basin with northeast dipping major faults (Fig. 1B), (ii) the Central basin (Belayim province) with southwest dipping major faults, and, (ii) the Southern basin (Amal-Zeit province) with northeast dipping major faults (Figs. 1 and 2). The sub-basins are separated by two major accommodation zones ca. 20-km wide (Colletta et al. 1988): the Zaafarana and the Morgan accommodation zones (Fig. 2).

The stratigraphic succession of the Gulf of Suez includes (i) pre-rift, (ii) syn-rift and (iii) postrift deposits (Fig. 3). (i) The pre-rift comprises a Precambrian Pan-African crystalline basement unconformably overlain by a $1-\mathrm{km}$ thick succession of Cambrian to Eocene sedimentary rocks progressively thinning southward. They are subdivided into three units (e.g. Moustafa 1976; Garfunkel and Bartov 1977): (1) the "Nubia Sandstones" mostly consist of fluvial sandstones (Cambrian to Early Cretaceous), (2) the Late Cretaceous mixed carbonate-siliciclastic succession and (3) the Paleocene-Eocene carbonate-dominated succession (Fig. 3). (ii) Red-bed deposits record the transition from pre-rift to syn-rift (Tayiba and Abu Zenima Formations) and are usually attributed to the Oligo-Miocene (Fig. 3). The overlying Miocene syn-rift succession is subdivided into the Gharandal Group (Nukhul, Rudeis and Kareem Formations) of mixed depositional environments, and 
the Ras Malaab Group (Belayim, South Gharib and Zeit Formations) dominated by evaporites (EGPC 1964; Fig. 3). (iii) Catchments feeding post-rift depositional systems developed on both pre-rift and syn-rift deposits. The post-Zeit, post-rift succession (Wardan and Zaafarana Formations; Figs. 3 and 4) is attributed to the Plio-Pleistocene (e.g. Abd El Shafy 1990). The mean tectonic subsidence was estimated ca. $31 \mathrm{~mm} / \mathrm{kyr}$ at that time (Bosworth et al. 1998).

\section{Data and method}

We expanded the database of Rohais et al. (2016) for the Plio-Pleistocene deposits taking into account previous findings for this time interval (e.g. Said 1962, 1990; Abdel Salam and ElTablawy 1970; Fawzi and Abdel Aal 1984; Abd El Shafy 1990; Gheith and El-Sherbini 1993; Alsharhan and Salah 1995, 1998; Rioual 1996; Orszag-Sperber et al. 1998). It includes high resolution digital topographic data, aerial maps, 279 subsurface wells, 31 sedimentological outcrop sections and published geological, structural, isopach and paleogeographic maps and cross-sections (see Rohais et al. 2016 and references herein).

We followed a seven steps workflow: five steps analyse the "sink" domain and two addresses the "source".

(i) From outcrop analysis, geological mapping, bibliographic review, seismic interpretation and well correlation we build structural maps of the basin (Fig. 2).

(ii) We then correlated key stratigraphic surfaces across the basin using a sequence stratigraphy analysis (Figs. 4 and 5).

(iii) From control wells, outcrop sections and published 3D geological models (Barrois et al. 2010; Barrois 2011), we build isopach and lithological maps using the present day structural framework (Fig. 6).

(iv) We estimated the relative proportion of siliciclastics (shales, sandstones, conglomerates), carbonates (carbonates and offshore mudstones) and evaporites (anhydrite and halite) deposits 
using an automatic image analysis on both the lithological maps and the cross sections (Table 1). We differentiated two end-members (maximum and minimum) and a mean scenarios to estimate the uncertainties associated with each lithologic component. From this, we estimated, for each time step, the volumes of each lithology and corrected them from remaining porosity using the method of Poag and Sevon (1989).

(v) To allow for the computation of accumulation rates and sediment supply (Table 1), we then calibrated the main stratigraphic surfaces into absolute ages. We used the few biostratigraphic constrains available and assumed that the major sequence boundaries were correlated to the ones of the International Commission on Stratigraphy (ICS) stratigraphic chart that includes the synthesis by Hardenbol et al. (1998), Haq and Al-Qahtani (2005) and Gradstein et al. (2012).

(vi) For the source areas, we quantified the drainage catchments characteristics (relief, area, length, slope, bedrock lithology). To do this, we used the Hydrology toolset from the Spatial Analyst toolbox available in ArcGIS on the $30 \mathrm{~m}$ resolution digital topographic data from ASTER GDEM (http://reverb.echo.nasa.gov/reverb/), as well as aerial maps (WGS 1984 UTM Zone 36N, https://www.microsoft.com/maps/).

(vii) From the present day climatic setting and catchment morphological parameters, we used the method of Syvitski et al. (2003) to predict a theoretical sediment supply (Qs) for each catchment from its relief $(R, m)$ and catchment area $\left(A, \mathrm{~km}^{2}\right)$ according to the empiric law:

$$
Q s=\alpha R^{3 / 2} A^{1 / 2}
$$

where $\alpha=\beta \varrho \mathrm{g}^{1 / 2}=2 \times 10^{-5}\left(\mathrm{M} \mathrm{L}^{-2.5} \mathrm{~T}^{-1}\right)$ with $\beta$ a constant of proportionality depending on the climate (Syvitski and Morehead 1999), @ the grain density $(2,650 \mathrm{~kg} / \mathrm{m3}) ; \mathrm{g}$ the acceleration due to gravity $\left(9.8 \mathrm{~m} / \mathrm{s}^{2}\right)$. Using these catchment characteristics, we then estimated the water discharge (Q) from the empirical relationship between discharge (Q) and catchment area (A) of Syvitski et al. 2003):

$Q=\alpha_{1} A^{\alpha 2}$ 
where $\alpha 1$, and $\alpha 2$ are constants determined using a regression analysis of a large river database. We used $\alpha 1=0.51$, and $\alpha 2=0.7$ defined for the north tropics (Syvitski et al. 2003). We verified these estimations with the present day river sediment supply in the Suez rift.

Assuming the drainage system remained constant throughout the Gulf of Suez history, we extrapolated the estimation of the theoretical Qs since the Miocene, using similar parameters.

\section{Sink: sedimentary budget for the Plio-Pleistocene}

\subsection{Stratigraphic architecture and age model}

For the sedimentology and lithostratigraphy of the Plio-Pleistocene sequence of the Suez rift, we used previous works by Said $(1962,1990)$, Abd El Salam and El Tablawy (1970), Fawzi and Abd El Al (1984), Abd El Shafy (1990), Gheith and El-Sherbini (1993), Alsharhan and Salah $(1995,1998)$, Bosworth and Taviani (1996), Rioual (1996), Orszag-Sperber et al. (1998) and Ali et al. (2010). However, the calibration in absolute ages within the Plio-Pleistocene succession remains poorly constrained, especially for the offshore domain (e.g. Ali et al. 2010). The base of the Wardan Fm is interpreted as the base Pliocene (ca. 5.3 Ma) overlying the Zeit Fm attributed to the Messinian (Abd El Shafy 1990). Above, the boundary between the Wardan and Zaafarana Formations is commonly attributed to the Plio-Pleistocene boundary (ca. $2.5 \mathrm{Ma}$ ) based on very limited biostratigraphical constrains (Abd El Shafy 1990; Gheith and El-Sherbini, 1993; Orszag-Sperber et al. 1998; Ali et al. 2010).

Using stacking pattern analysis, we identified correlated at rift scale seven units: from PQ1 for the earliest Pliocene to PQ7 for the most recent Quaternary (Figs. 4 and 5). We defined the stratigraphic architecture using six lithologies: carbonates (including reef and platform s.l. deposits), shales (silty-rich from protected to restricted deposits and mud-rich for offshore deposits), sandstones (including fan delta, shallow marine, and turdiditic deposits), conglomerates (including alluvial fan and proximal fan delta deposits), anhydrite, and halite (mainly from lagoon and saline to sabkha depositional settings). The PQ1 unit comprises deep basinal facies preserved along the basin 
axis organized in aggrading to backstepping trend (Fig. 5). It corresponds to a starved carbonate platform along the basin margins and a shallow siliciclastic deposits along the main accommodation zones. It records a progressive northward flooding of the Suez rift. The base of PQ2 is a major sequence boundary (Fig. 4). The PQ2 unit is characterized by thick halite deposits, associated to anhydrite-rich and restricted deposits, and is preserved in the Central basin (Fig. 5). These deposits were interpreted as marginal, semi-restricted lagoonal settings (Alsharhan and Salah 1998). As a difference, shallow platform deposits are preserved in the Southern basin, isolating the restricted Central Suez rift from the Red Sea whereas silicilastics deposits prevailed in the northern Darag basin (Fig. 5). The PQ3 unit is characterized by basinal to marginal facies organized in a prograding trend (Fig. 4). It recorded a single pulse of carbonates: a widening of the patch reef and carbonate platform in the Darag basin (Fig. 5). The PQ4 unit is characterized by $\mathrm{m}$-thick halite intervals associated to anhydrite-rich and restricted deposits preserved in the Darag basin (Fig. 5). As a difference with the PQ2 interval, there is no evidence for halite occurrence in the Central basin at that time. The PQ4 unit records the maximum backstep of the most restricted and evaporative depositional environment of the Plio-Pleistocene. The PQ5, PQ6 and PQ7 units correspond to basinal facies alternating with thin (m-scale) anhydrite layers organized in an overall prograding trend (Figs. 4 and 5). Over this period, siliciclastics including turbidites dominates the deposition in the Central basin and the western Darag basin whereas, in the Southern basin, a shallow platform facing an open marine environment to the south (Red Sea) developed, including evaporite, reefs and lagoonal deposits during lowstand periods. A longitudinal N-S depositional gradient then prevailed along the basin axis (Fig. 5).

To calibrate stratigraphic surfaces bounding these units in absolute ages, we used the ICS stratigraphic chart based on the synthesis by Gradstein et al. (2012; Fig. 4). We interpreted the high evaporite contents of PQ2 and PQ4 units as lowstand system tracts. Using ICS stratigraphic chart, we attributed the base of PQ2 unit to the 4Ma sea-level drop (Za2), the top of PQ2 unit to the 3.2Ma sea-level drop (Pia 1), the base of PQ4 unit to the 2.5Ma sea-level drop (Wardan to Zaafarana 
boundary, Ge1) and the top the PQ4 unit to the 1.65Ma sea-level drop (Cala 1). The PQ5, PQ6 and PQ7 unit calibration in absolute ages is poorly constrained and remains speculative. Nonetheless, as MIS22 and MIS12 are the two major sequence boundaries of this time interval, we attributed the base of the PQ6 unit to the $0.8 \mathrm{Ma}$ sea-level drop and the top of the PQ6 unit to the 0.4Ma sea-level drop. Our calibration is consistent with the recent work of Jackson and Rotevatn (2013) in the Central basin of the Suez rift.

\subsection{Lithology and paleogeography evolution}

As the Miocene, the Plio-Pleistocene shows alternating (i) overfilled phases with a transversal E-W depositional gradient from the rift margins to the basin axis (mainly highstands, Fig. 6b), and (ii) underfilled phases with a longitudinal N-S depositional gradient along the basin axis (mainly lowstands, Fig. 6c).

During highstands, the Darag basin shows a simple tilted block configuration, with a single alluvial to fan delta system fed by large catchment areas on the western (high-relief) footwall, and a starved shorelines with small isolated fan deltas, small patch reefs and isolated carbonate platforms on the eastern (low-relief) hanging wall (Fig. 6b). As a difference, during lowstands, the Darag basin was subaerially exposed with lagoonal to restricted depositional environments along the basin axis. Evaporites were locally preserved in small depocenters (Fig. 6c).

The Central basin had a similar configuration than the Darag basin with an inverse polarity: hanging wall to the west and footwall to the east (Fig. 6). During highstands, a 10-20 km wide bajada to alluvial fan system developed on the first tilted blocks of the western margin (low-relief hanging wall; Fig. 6). Small patch reefs and isolated platforms formed along starved shoreline as well. Large alluvial to fan delta systems (Wadi Baba, Feiran, Belayim) formed along the eastern margin (highrelief footwall) and fed turbidite systems preserved in the basin axis. As a difference, during lowstands, the Central basin was partially subaerially exposed. The basin axis showed lagoonal to 
restricted environments with large alluvial to fan delta system derived from the eastern margin (Fig. $6 c)$.

In the Southern basin, during highstands, $10-20 \mathrm{~km}$ wide bajada to alluvial fan systems formed along the rift shoulder and on the first set of tilted blocks (Zeit, Esh El Mellaha and El Qaa plains, Fig. 6b). They evolved into fan delta and starved shorelines prograding into lagoonal to open sea environments. Reefs and isolated carbonate platforms developed on tilted block crests and along starved shorelines, preferentially along the western margin where sediment supply from the catchments are stored and controlled by the tilted block crest (Zeit, Esh El Mellaha, Fig. 6). The basin axis preserved moderately deep deposits (50-80 m water depth). As a difference, during lowstands, the Southern basin was partially subaerially exposed with lagoonal to restricted environments in the basin axis. Evaporites were locally preserved in small depocenters (Fig. 6c). As suggested by seismic data, a carbonate platform is suspected to the south (towards the Red Sea; Rioual 1996).

\subsection{Isopach maps and sediment supply}

The main Plio-Pleistocene depocenters are fairly similar to the Late Miocene ones (Rohais et al. 2016) with nonetheless (i) an additional major depocenter in the Darag basin (Fig. 6a) and (ii) an overall tilt of the basin axis northward during the Plio-Pleistocene (Fig. 5). The Darag and Central basins preserved most of the sediments and the Southern basin subsided at a lower rate, probably in response to the Aqaba transform fault activity.

We estimated the total volume of Plio-Pleistocene sediments ca. $12,800 \mathrm{~km}^{3}$ and the incremental accumulated volumes of PQ1 to PQ7 units for each lithology are shown in Table1 (the remaining porosity correction was estimated between $30 \%$ at the base Pliocene and $40 \%$ at the top Quaternary for siliciclastics).

The carbonate accumulation rate is relatively constant over the Plio-Pleistocene (ca. 60-70 m/Myr, Fig. 7) and similar to the Miocene (Rohais et al. 2016). It is consistent with previous 
estimations that also suggested stable type of carbonates in the Suez rift over the whole the PlioPleistocene (Burchette 1988; Bosence et al. 1994). The carbonate accumulation rate also ranges in worldwide values published for the 0.5-2 Myr time interval (Davies 1988; Enos 1991).

The evaporite accumulation rate is relatively low during the Plio-Pleistocene (70 to 80 $\mathrm{m} /$ Myr) with nonetheless an acceleration during PQ4 (112 m/Myr; Table 1). The values are consistent with Miocene accumulation rates (Rohais et al. 2016) as well as previous estimations for the 0.5-2 Myr time interval (Decima and Wezel 1973; Enos 1991).

The sediment supply (Qs) ranges from 650 to $950 \mathrm{~km}^{3}$ /Myr during the Plio-Pleistocene (Fig. 7, Table 1). Taking into account the uncertainties, rates increased during the early Pliocene (PQ1) and decreased slightly during PQ2. They increased again progressively back to the previous rate during the late Pliocene (PQ3 and $\mathrm{PQ} 4)$, decreased slightly during the early Pleistocene (PQ5) before increasing to the maximum rate at the end of the Pleistocene (PQ6 and PQ7).

\section{Source: geomorphological characteristics}

We analyzed the present day catchment areas on aerials photos and a Digital Elevation Model (DEM) from which we extracted the catchments characteristics using the Hydrology toolset of ArcGIS with a $20 \mathrm{~km}^{2}$ cut-off for merging smallest catchment areas. We identified 68 catchments with an outlet feeding the Suez rift (Fig. 8) for which we measured (i) the relief (R) between the outlet and the maximum elevation in the catchment, (ii) the catchment area (A), (iii) the dominant lithology of the catchment bedrock (basement, siliciclastics or carbonates) using the geological map (EGSMA, 1981), (iv) the location of the outlet (Darag, Central or Southern basins) and (v) its tectonic setting (footwall or hanging wall). For catchments larger than $20 \mathrm{~km}^{2}$, and if occurring, we also measured the mean slope of the alluvial fans and/or bajadas ( $G f, m / m$ ), their areas (Af) and their bedrock lithology. Results are shown in Table 2 and Figure 9. Out of the 68 catchments, 13 do not have fan at the outlet and deliver sediments directly to the sea. 
At rift scale, the mean catchment relief is about $850 \mathrm{~m}$ (from 124 to 2,511 m), the mean area about $450 \mathrm{~km}^{2}$ (from 21 to $3,290 \mathrm{~km}^{2}$ ), the mean fan slope about $0.02 \mathrm{~m} / \mathrm{m}$ (from 0.005 to $0.05 \mathrm{~m} / \mathrm{m}$ ) and the mean fan area about $210 \mathrm{~km}^{2}$ (from 2.5 to $1,455 \mathrm{~km}^{2}$ ). This mean fan area is very large because most of the alluvial to fan delta system correspond to bajada in the Suez rift. Indeed, the Baba, Rudeis, and Sidri fan deltas, that could be considered as typical fan deltas, have an mean area of ca. $70 \mathrm{~km}^{2}$. Hereafter, we use the term fan for both alluvial and fan delta.

\subsection{Alluvial to fan delta systems}

The fans located on the footwalls of the three sub-basins (Darag, Central and Southern) show a similar fan gradient/area relationship (triangles on Fig. 9A), different than the fans located on the hanging walls (squares on Fig. 9A), excluding the fans located in the Central basin. The steepest fan systems are located in the hanging wall of the Southern basin whereas the gentlest are located in the hanging wall of the Darag basin. Steeper systems develop from crystalline basement, and gentlest from siliciclastic-dominated catchments (Fig. 9B). For crystalline basement catchment, fans are steeper on the hanging wall (e.g. Southern basin) whereas, for a more erodible bedrock (e.g. silicilastics) fan are steeper in the footwall (e.g. the Miocene, the recent alluvial and/or the poorly consolidated Paleozoic siliciclastic rocks of the Darag basin). The extracted dataset indicates that the fan slope depends on the catchment area by a negative power law, in agreement with the results of Bull (1964), Hooke (1968) and Saito and Oguchi (2005) (Figs. 9C and 9D; Table 3).

\subsection{Catchment areas}

The catchment relief $(R, m)$ relates to the catchment area $\left(A, \mathrm{~km}^{2}\right)$ by a positive power law (Table 3) that does not seem impacted by the tectonic setting or the bedrock lithology (Fig. 9E, 9F). The hanging wall of the Southern basin does however show a specific behavior, that is out of the dataset cluster and characterized by high catchment reliefs and relatively low catchment areas (Fig. 9E). This may be related to the combined effects of the crystalline bedrock, the tectonic setting and the vicinity of the Sinai Peninsula where important uplift occurred. Indeed, uplift along the Gulf of 
Suez increased southward on the Sinai Peninsula but remained more stable on the Egyptian side (Garfunkel 1988).

\subsection{Predicting the sediment supply and discharge}

Using Eq. (1), we estimated the predicted total sediment supply produced by the Suez rift catchments at about $970 \mathrm{~km}^{3} / \mathrm{Myr}$ which is remarkably similar to the value determined from the PQ7 (0-0.4 Ma) unit volume (about $940 \mathrm{~km}^{3} / \mathrm{Myr}$; ranging from $850-1,000 \mathrm{~km}^{3} / \mathrm{Myr}$ ).

Using Equation (2), we estimated the mean water discharge at rift scale between 1,500 to $1,800 \mathrm{~m}^{3} / \mathrm{s}$ during the Plio-Pleistocene (variations are small with respect to uncertainties; Fig. 10 , Table 4). These values are consistent with present-day hydrographic study of Geriesh et al. (2004) for the Suez rift.

\subsection{Estimating the Plio-Pleistocene relief, catchment size and uplift rate}

We used the relative proportion of each catchment area to the total sediment supply (Qs) at present day to (i) estimate the past sizes of catchments (during time intervals PQ1 to PQ7) assuming they had the present-day relief. (ii) Alternatively, we estimate past reliefs of catchments assuming they had the present-day area (Fig. 10, Table 4). We estimated uncertainties in our calculation from the uncertainties associated to the sediment supply quantification.

Assuming the catchment areas remained constant throughout Plio-Pleistocene, the estimated mean relief of catchment remained similar to the present-day (about $850 \mathrm{~m}$ ) over that period (variations are small with respect to uncertainties; Fig. 10). Assuming the catchment relief remained constant throughout Plio-Pleistocene, the estimated mean catchment remained similar to the present-day $\left(450 \mathrm{~km}^{2}\right)$ over that period (variations are small with respect to uncertainties; Fig. 10). 
These estimations suggest relief remained at equilibrium throughout the Plio-Pleistocene, (uplift rate balanced by erosion rate). We can therefore estimate the mean uplift rate at about 0.03 $\mathrm{km} / \mathrm{Myr}(+/-0.0025)$ during the last $0.4 \mathrm{Myr}$ from the present-day total catchment area (about $31,000 \mathrm{~km}^{2}$ ) and the most recent sedimentary supply (PQ7, 0-0.4 Ma, about $940 \mathrm{~km}^{3} / \mathrm{Myr}$ ). This rate is three times lower than the maximum uplift estimated on tilted block crest of the southern Suez rift for the Pleistocene (about $0.1 \mathrm{~km} /$ Myr in the Gebel Zeit area; Bosworth and Taviani 1996; Plaziat et al. 1998). It is however consistent with the mean uplift values estimated at basin-scale ca. 0.01-0.06 km/Myr by Plaziat et al. (1998) for the Pleistocene.

\section{Discussion}

\subsection{The Pliocene revolution?}

We bring here our estimations of accumulation rates for the Plio-Pleistocene in perspective with the estimations for the Oligo-Miocene of the Suez rift by Rohais et al. (2016; Fig. 10). Over that period, the sediment supply followed an expected trend during a rifting. From the rift initiation to the rift climax phases, sediment supply increased rapidly (up to almost $1,400 \mathrm{~km}^{3} / \mathrm{Myr}$ at the end of the Rudeis Fm deposition). It then decreased down to ca. $50 \mathrm{~km}^{3} / \mathrm{Myr}$ during the late to latest syn-rift phases that corresponds to a subdued tectonic (Kareem, Belayim and South Gharib Fms; LanghianSerravalilan-Tortonian). However afterwards, during the post-rift, sediment supply unexpectedly peaked up again up to almost $900 \mathrm{~km}^{3} / \mathrm{My}$ in the lower Pliocene (PQ1) and remained between 650 and $850 \mathrm{~km}^{3} / \mathrm{Myr}$ throughout the Plio-Pleistocene, i.e. within values similar to the rifting climax. Experimental and numerical modeling (e.g. Bonnet and Crave 2003; Rohais et al. 2012) suggest that the increase of the uplift rate in the catchment areas could produce this increase in sediment supply. This increase in uplift rate is also consistent with the post-rift renewal of tectonic subsidence documented in the sedimentary basin from backstripping methods (Fig. 10).

The similar amplitude of sediment supply during rift climax (Burdighalian) and post-rift (PlioPleistocene) phases could suggest similar uplift rates assuming similar catchment areas and reliefs. 
However, the Pleistocene uplift rate estimated at basin-scale or along the crest of tilted block in the Southern basin (ca. 0.01-0.1 km/Myr; Bosworth and Taviani 1996; Plaziat et al. 1998) is 2 to 80 times lower than the uplift rate estimated during the rift climax (Steckler 1985; Garfunkel 1988; Steckler et al. 1988; Steckler and Omar 1994). We therefore suggest an additional control on the PlioPleistocene increase of the sediment supply.

Peizhen et al. (2011) suggested a global-scale increase in accumulation of coarser sediments 2-4 Myr ago triggered by the "Pliocene revolution", i.e. a shift from a relatively stable climate during the Miocene to a high frequency glacial/interglacial oscillating one in the Plio-Pleistocene. This interpretation should be moderated because it is based on sediment thicknesses not corrected from remaining porosity that could introduce up to $50 \%$ uncertainties in volume estimation in the recent deposits because they undergo major porosity changes in the first 500 to $1,000 \mathrm{~m}$ of burial. Nonetheless, our estimations in the Suez rift are corrected from remaining porosity and their increase is coeval with the occurrence of this global climate shift. The amplitude and magnitude of the phenomenon remain nevertheless to be determined.

Evaporites accumulation rates at rift scale are a proxy for the long-term aridification in the Suez rift during the Late Miocene and of the Plio-Pleistocene high frequency climatic changes (Fig. 10). However, the stratigraphic resolution is no sufficient to identify high frequency trends in accumulation rates as expected between glacial/interglacial periods. These trends have been however documented in the Corinth rift with accumulation values for the lowstand glacial periods $60 \%$ higher than during interglacial highstand periods (Collier et al. 2000). These high frequency sediment supply oscillations produced an overall increase of the mean sediment supply over the PlioPleistocene. This suggests that the increase in sediment supply in the Suez rift at that time is consistent with the transition to glacial/interglacial oscillations during the "Pliocene revolution".

\subsection{Additional feedbacks}


The accumulation history during the rift evolution could also be used to discuss and refine the calibration in absolute age of some poorly constrained of the stratigraphic horizons. Indeed, the accumulation peak at the end of the Belayim Fm deposition may be related to an underestimation of the duration of that time interval rather than to an actual increase in siliciclastic sediment supply. It is in fact coeval of a peak in in situ carbonate accumulation, that is peculiar and unexpected as both types of accumulation should evolve in opposite phase. Assigning an $11.5 \mathrm{Ma}$ to the transition between Belayim and South Gharib Fm (instead of $11.8 \mathrm{Ma}$ ) would divide the estimated accumulation rate by two. These updated siliclastic and carbonate accumulation rates would be more consistent with the estimations for the previous and following periods and their geodynamic context (tectonic quiescence). This would however not alter significantly the accumulation rates for the following South Gharib Fm deposition period since the duration of that interval would be reduced by only $13.5 \%$. Avoiding any circular reasoning, this illustrates how S2S analyses may also provide additional constraints and feedbacks on the age model by highlighting accumulation rate anomalies in the frame of a well-known basin evolution.

\subsection{Limits of the approach}

This study illustrates a workflow allowing quantification of the sediment supply dynamics in a sedimentary basin and its discussion in term of sediment production from the catchment areas (erosion). We estimated the relief and the catchment area over the rift evolution (from the rift initiation to the post-rift) assuming stable catchments at rift scale both in terms of size and erodability (i.e. lithology). Many studies however demonstrated rapid catchment area growth and variations in similar tectonic contexts (Bishop 1995; Attal 2009; Bonnet 2009; Willet et al. 2014). Surface process modeling (SPM) would provide a tool to integrate the catchment variability in the evaluation of the sediment production through time. Also, to constrain paleo-climate modeling, the runoff, precipitations and temperatures evolution during the rift history could be estimated using the approach of Styvisky et al. (2003), that has been recently updated by Eide et al. (2017). 
To fully discuss the sediment supply dynamics during the basin history, we showed that sediment budget should be quantified at high resolution, at least in the same order of duration than response time of the system to a given control (glacial/interglacial climate oscillations for example). Otherwise, sediment supply dynamics might be misinterpreted (climate versus tectonic). For example, in this study, the increase in sediment supply at the Miocene/Plio-Pleistocene transition may be interpret just in terms of tectonic change (non-transient uplift increase), missing the climatic signal ("Pliocene revolution"). Also, estimating sediment supply for even duration time step throughout the basin evolution would avoid trends related only to scaling and allow a discussion of the response times between the areas of sediment production and accumulation. In that respect, a major limit to this work is lack of biostratigraphic constraints within the Plio-Pleistocene. Concluding remarks of this paper should therefore be updated by future works on biostratigraphy or absolute dating.

\section{Conclusion}

We studied the Plio-Pleistocene evolution of the Suez rift using an integrated S2S approach from the sedimentary basin ("sink") to the upstream catchment area ("source").

(1) The quality of the dataset is critical to undertake this type of studies: the geometries, facies and lithologies of deposits, their calibration in absolute ages as well as the type and timing of deformation need to be addressed to allow for the sedimentary budget quantification. Also, the sediment routing system needs to be as closed as possible to avoid loss (or gain) of sediments between the sources and the sinks. In situ production and remaining porosity must be properly corrected to extract the siliciclastic sediment supply that is the only one relevant to discuss the catchment dynamics. First-order constraints on the location and size of sediment sources and on the sediment routing systems can be derived from geological mapping. A quantification of the siliciclastic sedimentary budget can then provide first order constraints on paleo-reliefs. Nevertheless, 
deformation or climate driven changes in regional drainage patterns requires numerical experimentation using surface-process models to be integrated in the analysis.

(2) Quantitative geomorphology analysis of the most recent systems allowed determining the relationships between sediment supply and catchment properties (area, relief, gradient, lithology). Assuming the present day configuration is representative of the past basin evolution in the Suez rift, those relationships were used to assess the first order relief dynamics at geological time-scale. It also provided first-order estimations of temperature, runoff and precipitations very useful in past climate modeling.

(3) The sediment supply dynamics of the Plio-Pleistocene deposits of the Suez rift shows a renewed uplift ca. 5 Myr ago. Nonetheless, a major climate shift related to the Pliocene revolution was most probably coeval to reach the magnitude of accumulation observed. To decipher the relative contribution of uplift or climate, the sediment budget should be quantified at higher resolution (time steps lower than the system response time), although surface process modeling (SPM) might also help address this question. 


\section{REFERENCES}

Abd El Shafy A (1990) Miocene-Pliocene boundary in the Gulf of Suez region, Egypt. 10th EGPC Exploration Seminar, Cairo, Egypt, 1:213-233

Abdel Salam H and El-Tablawy M (1970) Pliocene diatom assemblage from East Bakr and East Gharib Exploratory wells in Gulf of Suez. Seventh Arab Petroleum Congress, Kuwait. 57(B-3).

Ali DM, El-Awamri AA, Badawi AA, Hamed AF (2010) Fossil diatoms in Zaafarana Formation, Gulf of Suez, Egypt. International Journal of Academic Research. Vol. 2. No. 6. November, 2010, Part I., 91100

Allen, P.A. (2008) From landscapes into geological history. Nature, 451, 274-276.

Alsharhan AS and Salah MG (1995) Geology and hydrocarbon habitat in rift setting: northern and central Gulf of Suez, Egypt: Bulletin of Canadian Petroleum Geology, v. 43, no. 2, p. 156-176.

Alsharhan AS and Salah MG (1998) Sedimentological aspects and hydrocarbon potential of the Quaternary in the Gulf of Suez rifted basin, in A. S. Alsharhan, K. W. Glennie, G. L. Whittle, and C. G. St. C. Kendall, eds., Quaternary deserts and climatics changes: Rotterdam, Balkema, p. 531-538.

Attal M (2009) Rivers split as mountains grow. Nat. Geosci. 2, 747-748, doi:10.1038/ngeo675 Babault J, van den Driessche J, Bonnet S, Castelltort S, Crave A (2005) Origin of the highly elevated Pyrenean peneplain. Tectonics, 24, doi: 10.1029/2004TC001697.

Barnes JB and Heins WA (2009) Plio-Quaternary sediment budget between thrust belt erosion and foreland deposition in the central Andes, southern Bolivia. Basin Research 21, 91-109, doi: 10.1111/j.1365-2117.2008.00372.x

Barrois A (2011) Couplage d'un modèle structural 3D restauré (Kiné3D-3) avec un modèle de remplissage stratigraphique (Dionisos) en contexte extensif, cas du rift de Suez (Égypte). I.F.P. report 62044

Barrois A, Rohais S, Granjeon D, Rudkiewicz JL, Cacas MC (2010) Coupling 3D Structural Restoration with Stratigraphic Modelling in Rifted Margins, Suez Rift, Egypt. International conference "Modelling sedimentary basins and their petroleum systems", June 3-4th 2010, Geol. Soc. London

Bishop P (1995) Drainage rearrangement by river capture, beheading and diversion. Prog. Phys. Geogr. 19, 449-473. doi: 10.1177/030913339501900402

Bonnet S and Crave A (2003) Landscape response to climate change: insights from experimental modeling and implications for tectonic vs. climatic uplift of topography. Geology 31: 123-126

Bonnet S (2009) Shrinking and splitting of drainage basins in orogenic landscapes from the migration of the main drainage divide. Nat. Geosci. 2, 766-771. doi: 10.1038/ngeo666

Bosence DWJ, Pomar L, Waltham D, Lankester TG (1994) Computer modelling a Miocene carbonate platform. Spain. American Association Petroleum Geologists Bulletin, 78, 247-266. 
Bosworth W and Taviani M (1996) Late Quaternary reorientation of stress field and extension direction in the southern Gulf of Suez, Egypt: Evidence from uplifted coral terraces, mesoscopic fault arrays, and borehole breakouts. Tectonics, 15, 791-802

Bosworth W, Crevello P, Winn Jr RD, Steinmetz J (1998) Structure, sedimentation, and basin dynamics during rifting of the Gulf of Suez and north-western Red Sea. In: Purser, B.H., Bosence, D.W.J. (Eds.), Sedimentation and Tectonics in Rift Basins: Red Sea - Gulf of Aden. Chapman Hall, London, pp. 77-96.

Bull WB (1964) Relation of alluvial fan size and slope to drainage basin size and lithology in western Fresno County, California. U.S. Geological Survey Professional Paper 450-B: 51-53

Burchette TP (1988) Tectonic control on carbonate platform facies distribution and sequence development: Miocene, Gulf of Suez. Sedimentary Geology, 59, 179-204.

Colletta B, LeQuellec P, Letouzey J, Moretti I (1988) Longitudinal evolution of the Suez rift structure (Egypt). Tectonophysics 153, 221-233

Collier REL, Leeder MR, Trout M, Ferentinos G, Lyberis E, Papatheodorous G (2000) High sediment yields and cool, wet winters: rest of past glacial paleoclimates in the northern Mediterranean. Geology 28 (11): 999-1002

Davies PJ (1988) Evolution of the Great Barrier Reef: reductionist dream or expansionist vision. Proc. 6th Int. Coral Reef Symp., Townsville 1, 9-17

Decima A and Wezel FC (1973) Late Miocene evaporites of the Central Sicilian Basin. In: Initial Reports of the Deep Sea Drilling Project (Eds W.B.F. Ryan and K.J. Hsü), Vol. 13, Part 2, pp. 12341240. U.S. Government Printing Office, Washington, DC

EGSMA, 1981. Egyptian Geologycal survey and mining Authority, Geological map of Egypt, 1981. Ministry of Industry and Mineral Resources

Egyptian General Petroleum Corporation, EGPC (1964) Oligocene and Miocene rock- stratigraphy of the Gulf of Suez region, report of the Stratigraphic Committee: Egyptian General Petroleum Corporation, $142 \mathrm{pp}$

Eide CH, Muller R, Helland-Hansen W (2017) Using climate to relate water-discharge and area in modern and ancient catchments. Sedimentology, 10.1111/sed.12426

Einsele G, Ratschbacher L, Wetzel A (1996) The Himalaya-Bengal Fan denudation-accumulation system during the past 20Ma. J. Geol., 104, 163-184.

Enos P (1991) Sedimentary Parameters for Computer Modeling, Sedimentary Modeling: Computer Simulation and Methods for Improved Parameter Definition, ed. E. K. Franseen, W. L. Watney, C. G. St. C. Kendall and W. Ross, Kansas Geological Survey, 233, 63-98

Fawzy H and Abdel Aal A (1984) Regional study of Miocene evaporates and Pliocene-recent sediments in the Gulf of Suez. In Egyptian General Petroleum Corporation. 7th EGPC Exploration Seminar, Cairo, Egypt, 49-74 
Garfunkel Z and Bartov Y (1977) The tectonics of the Suez rift. Geol Surv Isr Bull 71:45

Garfunkel Z (1988) Relation between continental rifting and uplifting: evidence from the Suez rift and northern Red Sea. Tectonophysics, v. 150, pp. 33-49

Geriesh MH, El-Rayes AE, Fouad A (2004) Runoff control and water management in Wadi Ghweabae hydrographic basin, Northwest of Gule of Suez region, Egypt. Proc. 7th Conf. Geology of Sinai for Development, Ismailia, 2004, pp. 53-67

Gheith AM and El-Sherbini ME (1993) Post-Miocene Sedimentation in the Gulf of Suez, Egypt. JKA U Mar Sci 4:73-92

Gradstein FM, Ogg JG, Schmitz MD, Ogg GM (2012) The Geologic Time Scale. Elsevier doi:10.1016/B978-0-444-59425-9.10003-4

Guillocheau F, Rouby D, Robin C, Helm C, Rolland N, Le Carlier de Veslud C, Braun J (2012) Quantification and causes of the terrigeneous sediment budget at the scale of a continental margin: a new method applied to the Namibia-South Africa margin. Basin Research, 24: 3-30. doi: 10.1111/j.1365-2117.2011.00511.x

Hampson GJ, Duller RA, Petter AL, Robinson RAJ, Allen PA (2014) Mass-balance constraints on stratigraphic interpretation of linked alluvial-coastal-shelfal deposits from source to sink: example from Cretaceous Western Interior Basin, Utah and Colorado, U.S.A. J. Sediment. Res., 84, 935-960.

Haq BU and Al-Qahtani AM (2005) Phanerozoic cycles of sea-level change on the Arabian Platform: GeoArabia, v. 10/2, p. 127-160.

Hardenbol J, Thierry J, Farley MB, Jacquin T, de Graciansky PC, Vail P (1998) Mesozoic and Cenozoic sequence chronostratigraphic framework of European basins, in P.C. Graciansky, et al. (eds) Mesozoic and Cenozoic Sequence Stratigraphy of European Basins: SEPM Special Publication 60, p. 313 , charts 1-8.

Hooke RL (1968) Steady-state relationships on arid-region alluvial fans in closed basins. American Journal of Science 266: 609-629

Jackson CA-L and Rotevatn A (2013) 3-D seismic analysis of the structure and evolution of a saltinfluenced normal fault zone: a test of competing fault growth models. J. Struct. Geol., 54 (2013), pp. 215-234

Kennan L, Lamb SH, Hoke L (1997) High-altitude palaeosurfaces in the Bolivian Andes; evidence for late Cenozoic surface uplift. In: Palaeosurfaces; Recognition, Reconstruction and Palaeoenvironmental Interpretation (Ed. byM.Widdowson), Spec. Publ. Geol. Soc. Lond., 120, 307323.

Milliman JD and Syvitski JPM (1992) Geomorphic/tectonic control of sediment discharge to the ocean: the importance of small mountainous rivers. Journal of Geology 100, 525-544.

Moretti I and Colletta B (1987) Spatial and temporal evolution of the Suez Rift subsidence. J. Geodyn. 7, 151-168 
Moustafa AG (1976) Block faulting in the Gulf of Suez. Proceedings of the 5th Petroleum Exploration and Production Seminar, Egypt, v. 1, 19p.

Moustafa AR (1996) Internal structure and deformation of an accommodation zone in the northern part of the Suez rift. Journal of Structural Geology, 18, 93-107

Mulder T and Syvitski JPM (1996) Climatic and morphologic relationships of rivers. Implications of sea level fluctuations on river loads. Journal of Geology 104, 509- 523.

Orszag-Sperber F, Purser BH, Rioual M, Plaziat JC (1998) Post Miocene sedimentation and rift dynamics in the southern Gulf of Suez and northern Red Sea; In: Sedimentation and tectonics of rift basins: Red Sea-Gulf of Aden (eds) Purser B H and Bosence D W J, Chapman and Hall, London, pp. 427-447.

Patton TL, Moustafa AR, Nelson RA, Abdine SA (1994) Tectonic evolution and structural setting of the Suez Rift. In S.M. London (Ed.), Interior rift basins. American Association of Petroleum Geologists Memoir No. 59, p. 7-55

Pechlivanidou S, Cowie PA, Hannisdal B, Whittaker AC, Gawthorpe RL, Pennos C, Riiser OS (2017) Source-to-sink analysis in an active extensional setting: Holocene erosion and deposition in the Sperchios rift, central Greece. Basin Res. doi:10.1111/bre.12263

Peihzen Z, Molnar P, Downs WR (2001) Increase sedimentation rates and grain sizes 2-4 Myr ago due to the influence of climate change on erosion rates. Nature $410,891-897$

Plaziat J-C, Baltzer F, Choukri A, Conchon O, Freytet P, Orszag-Sperber F, Raguideau A, Reyss J-L (1998). Quaternary marine and continental sedimentation in the northern Red Sea and Gulf of Suez (Egyptian coast): influences of rift tectonics, climatic changes and sea-level fluctuations. In: Purser B.H., Bosence D.W.J. (eds) Sedimentation and Tectonics in Rift Basins Red Sea:- Gulf of Aden. Springer, Dordrecht

Poag CW and Sevon WD (1989) A record of Appalachian denudation in Post-Rift Mesozoic and Cenozoic sedimentary deposits of the U.S. Middle Atlantic Continental margin. Geomorphology, 2, $119-157$

Richardson M and Arthur MA (1988) The Gulf of Suez-northern Red Sea Neogene rift: a quantitative basin analysis. Marine Pet. Geol. 5, 247-270

Rioual M (1996) Sedimentation et tectonique post-Miocene dans le rift du Golfe de Suez et le NW de la Mer Rouge (Egypte). Doctoral Thesis, Universite de Paris Sud, 240 pp.

Rohais S, Bonnet S, Eschard R (2012) Sedimentary record of tectonic and climatic erosional perturbations in an experimental coupled catchment-fan system. Basin Research, 24: 198-212. doi: 10.1111/j.1365-2117.2011.00520.x

Rohais S, Barrois A, Colletta B, Moretti I (2016) Pre-salt to salt stratigraphic architecture in a rift basin: insights from a basin-scale study of the Gulf of Suez (Egypt). Arab. J. Geosci., 9, p. 317, $10.1007 / \mathrm{s} 12517-016-2327-8$ 
Rouby D, Bonnet S, Guillocheau F, Gallagher K, Robin C, Biancotto F, Dauteuil O, Braun J (2009) Sediment supply to the Orange sedimentary system over the last150 My: an evaluation from sedimentation/denudation balance. Mar. Petrol. Geol., 26, 782-794

Said R (1962) The Geology of Egypt. Elsevier Pub!. Co., Amsterdam, New York, 377 p.

Said R (1990) Cenozoic. In: Said, R. (Ed.), The Geology of Egypt. Balkema, Rotterdam, pp. 451-486.

Saito K and Oguchi T (2005) Slope of alluvial fans in humid regions of Japan, Taiwan, and Philippines. Geomorphology 70: 147-162

Sømme TO, Helland-Hansen W, Martinsen OJ, Thurmond JB (2009) Relationships between morphological and sedimentological parameters in source-to-sink systems: a basis for predicting semi-quantitative characteristics in subsurface systems. Basin Res., 21, 361-387.

Steckler MS (1985) Uplift and extension at the Gulf of Suez: indications of induced mantle convection. Nature 317, 135-139

Steckler MS, Bertholot F, Lyberis N, Le Pichon X (1988) Subsidence in the Gulf of Suez: implications for rifting and plate kinematics. Tectonophysics 153, 249-270

Steckler MS and Omar GI (1994) Controls on erosional retreat of the uplifted rift flanks at the Gulf of Suez and northern Red Sea. Journal of Geophysical Research, 99, 12159-12173.

Syvitski JPM and Morehead MD (1999) Estimating river - sediment discharge to the ocean: application to the Eel Margin, northern California. Marine Geology 154, 13- 28.

Syvitski JPM, Peckham SD, Hilberman RD, Mulder T (2003) Predicting the terrestrial flux of sediment to the global ocean:a planetary perspective. Sediment. Geol. 162:5-24, (doi:10.1016/j.sedgeo.2003.11.001).

Whitakker AC, Attal M, Allen PA (2010) Characterising the origin, nature and fate of sediment exported from catchments perturbed by active tectonics. Basin Res., 22, 809-828.

Willett SD, McCoy SW, Perron JT, Goren L, Chen C-Y (2014) Dynamic Reorganization of River Basins. Science 343,1248765 . DOI: 10.1126/science.1248765 


\section{FIGURE CAPTION}

Figure 1: (A) Geodynamic setting of the Gulf of Suez. Major elements including the Aqaba-Levant intra-continental transform boundary, the Bitlis-Zagros convergence zone and the Red Sea - Gulf of Aden are highlighted. The red rectangle shows the Gulf of Suez that corresponds to the NW termination of the Red Sea. Light blue corresponds to present day marine setting (modified after Rohais et al. 2016 and references herein). (B) Structural cross-section of the Suez rift illustrating the large scale tilted block structure of the Darag Basin (modified after Colletta et al. 1988). Blue arrows indicate the present day shoreline.

Figure 2: Structural map of the Suez rift and location of the dataset used in this study. Hatched areas indicate major accommodation zones separating from north to south: the Darag basin, the Central Basin and the Southern Basin. Red lines show the cross-sections presented in Figure 5.

Figure 3: Simplified stratigraphic column of the Suez rift (modified after Rohais et al. 2016 and references herein). The present study is focused on the post-rift series including the Wardan and Zaafarana Formations. See Figure 5 for lithology colour code.

Figure 4: Synthetic stratigraphic framework of the Plio-Pleistocene of the Suez rift. Lithologies are constrained from calibration wells. Silty rich for restricted deposits in green versus mud rich for offshore deposits in light blue. Transgressive system tracts are shown in blue, highstand and falling stage system tracts are shown in red, lowstand system tracts are shown in orange. The age model is derived from the ICS (2004), Hardenbol et al. (1998), Haq and Al-Qahtani (200) and Gradstein et al. (2012) stratigraphic charts

Figure 5: Transversal cross-section of the rift flattened on the present day topography showing (A) the main depositional units and (B) the main lithology. E-W cross section of the Central Basin flattened on the present day topography showing (C) the main depositional units and (D) the main lithology within the. Sections cross-cut at well 13. See Figure 2 for location.

Figure 6: (A) Maps of the Plio-Quaternary deposits and the main depocenters ( $>1700 \mathrm{~m})$ and dominant lithologies for the highstand (B. present day) and lowstand (C. PQ4, ca. 1.8 Ma). Silty rich shales for restricted deposits are shown in green. Mud rich shales for offshore deposits in light blue. See Figure 5 for further keys information.

Figure 7: Accumulation rates of evaporates and carbonates $\left(\mathrm{km}^{3} / \mathrm{Myr}\right)$ and mean sediment supply from siliciclastics $\left(\mathrm{km}^{3} / \mathrm{Myr}\right.$ ) for the Plio-Pleistocene deposits. The chronostratigraphy and sea-level curve are derived from Gradstein et al. (2012). Relative proportions of lithologies for each map have 
been combined with thickness map to estimate the accumulation rate. See text for further information.

Figure 8: Simplified geological and structural map showing the dominant lithology, size and shape of present day catchments. See Table 2 for the quantified parameters.

Figure 9: Characterization of the catchment areas (Source) in the Suez rift. A. Relationship between the fan gradient $(\mathrm{m} / \mathrm{m})$ to the fan area $\left(\mathrm{km}^{2}\right)$ of the fans according to the sub-basin and the tectonic setting (hangingwall - HW or footwall - FW). Blue: Southern Basin - SOB, Green: Central Basin - CEB, Yellow: Darag Basin - DAB. Square for hangingwall and triangle for footwall. B. Relationship between the fan gradient $(\mathrm{m} / \mathrm{m})$ to the fan area $\left(\mathrm{km}^{2}\right)$ of the fans according to the dominant lithology in the catchments. Blue for carbonate, red for basement and yellow for siliciclastic from the geological map in Figure 8. C, D: Relationship between the fan gradient $(\mathrm{m} / \mathrm{m})$ to the catchment area $\left(\mathrm{km}^{2}\right)$. E, F: Relationship between the catchment relief $(\mathrm{m})$ to the catchment area $\left(\mathrm{km}^{2}\right)$.

Figure 10: Mean accumulation rates of evaporites, carbonates and siliciclastics sediment supply $\left(\mathrm{km}^{3} / \mathrm{Myr}\right)$ and cumulative tectonic subsidence. The grey area includes all the wells analyzed for estimating the cumulative tectonic subsidence (modified from the wells analyzed by Moretti and Colletta 1987; Richardson and Arthur 1988). The chronostratigraphy and global sea-level curve are after Gradstein et al. (2012). The present day values for the mean relief (847 m) and mean catchment area $\left(454 \mathrm{~km}^{2}\right)$ are represented with dash lines. See text for further information. 


\section{TABLE CAPTION}

Table 1

Results of the sedimentary budget characterization for the Plio-Pleistocene deposits of the Suez rift. The preferred scenario is highlighted in grey. See text for further explanation.

Table 2

Database extracted using the Hydrology toolset from the Spatial Analyst toolbox developed in ArcGIS for the Suez rift. The relief $(R, m)$ corresponds to the maximum altitude in the catchment minus the altitude of the outlet.

Table 3

Regression coefficients established in Figure 9.

$\mathrm{Gf}=\alpha_{3} \mathrm{Af}^{\alpha 4}$

$G f=\alpha_{5} A^{\alpha 6}$

$R=\alpha_{7} A^{\alpha 8}$

\section{Table 4}

Results for the estimated mean relief $(\mathrm{m})$, mean catchment area $\left(\mathrm{km}^{2}\right)$ and mean discharge $\left(\mathrm{km}^{3} / \mathrm{Myr}\right)$ at rift scale based on the sediment supply (Qs) quantification and using the relationships of Syvitski et al. (2003). See text for further explanation. 


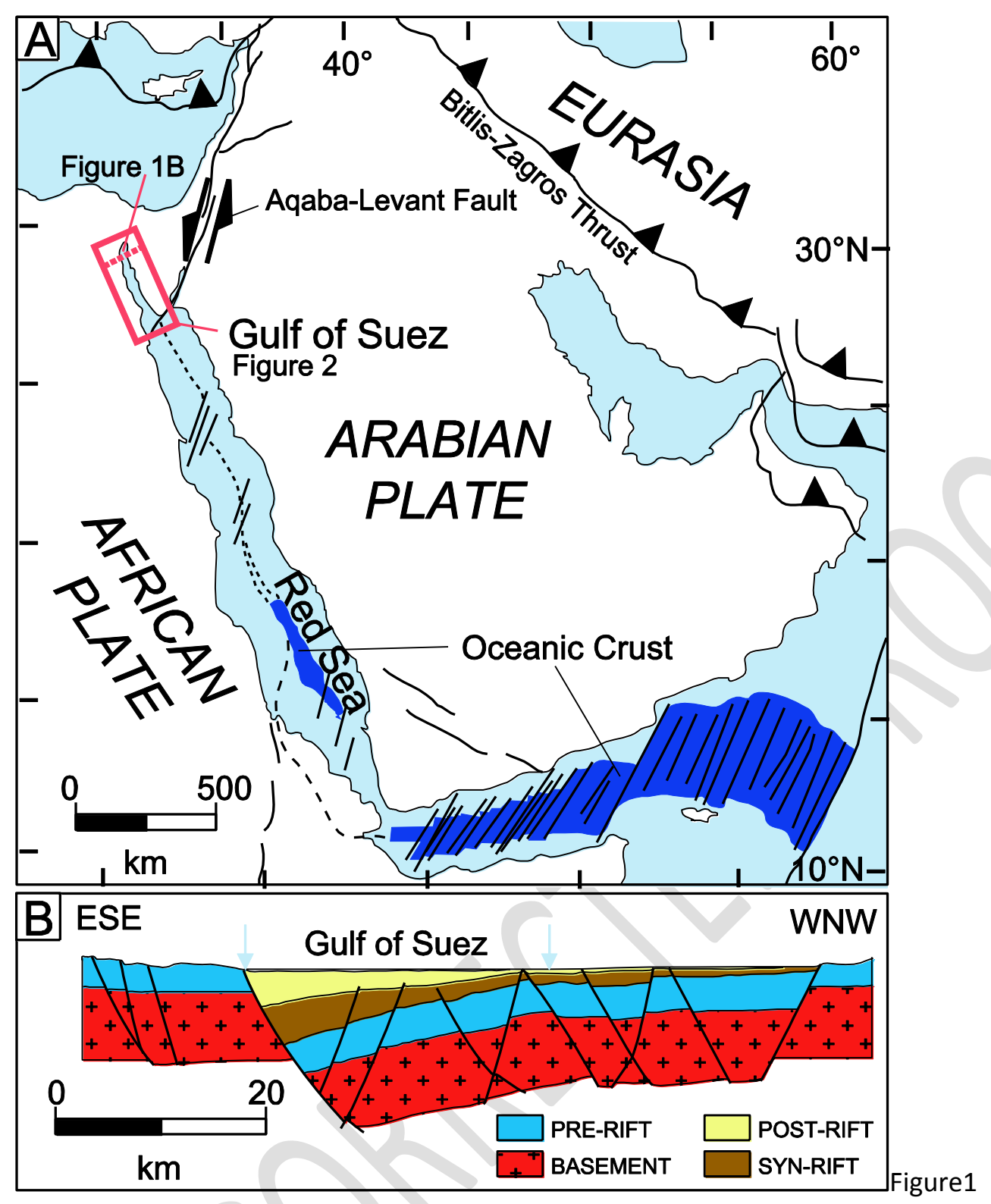




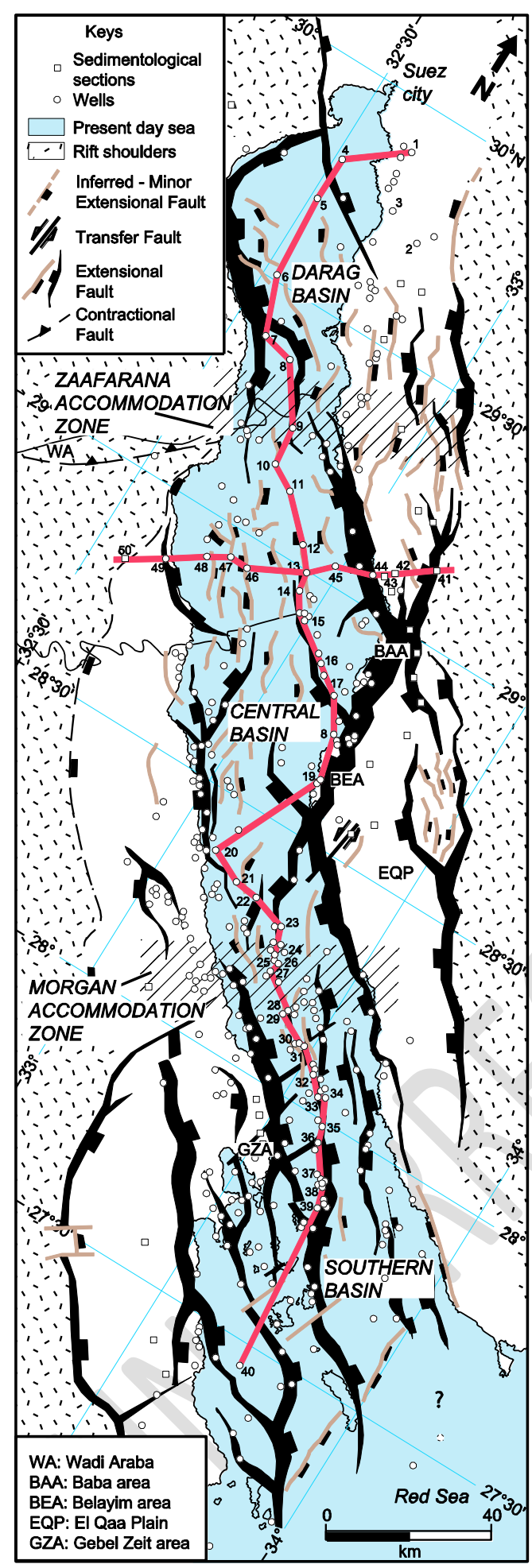

Figure2 


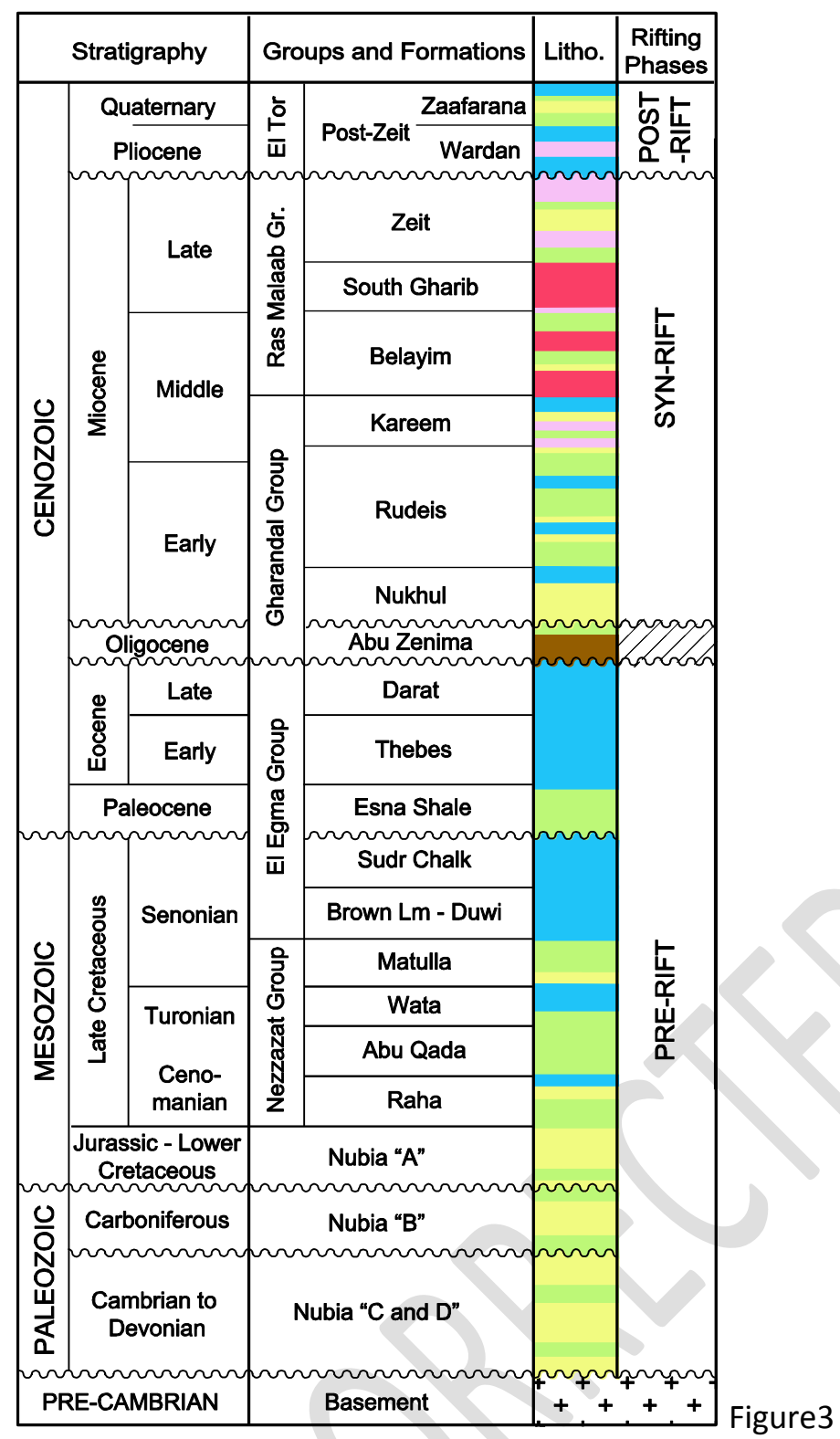




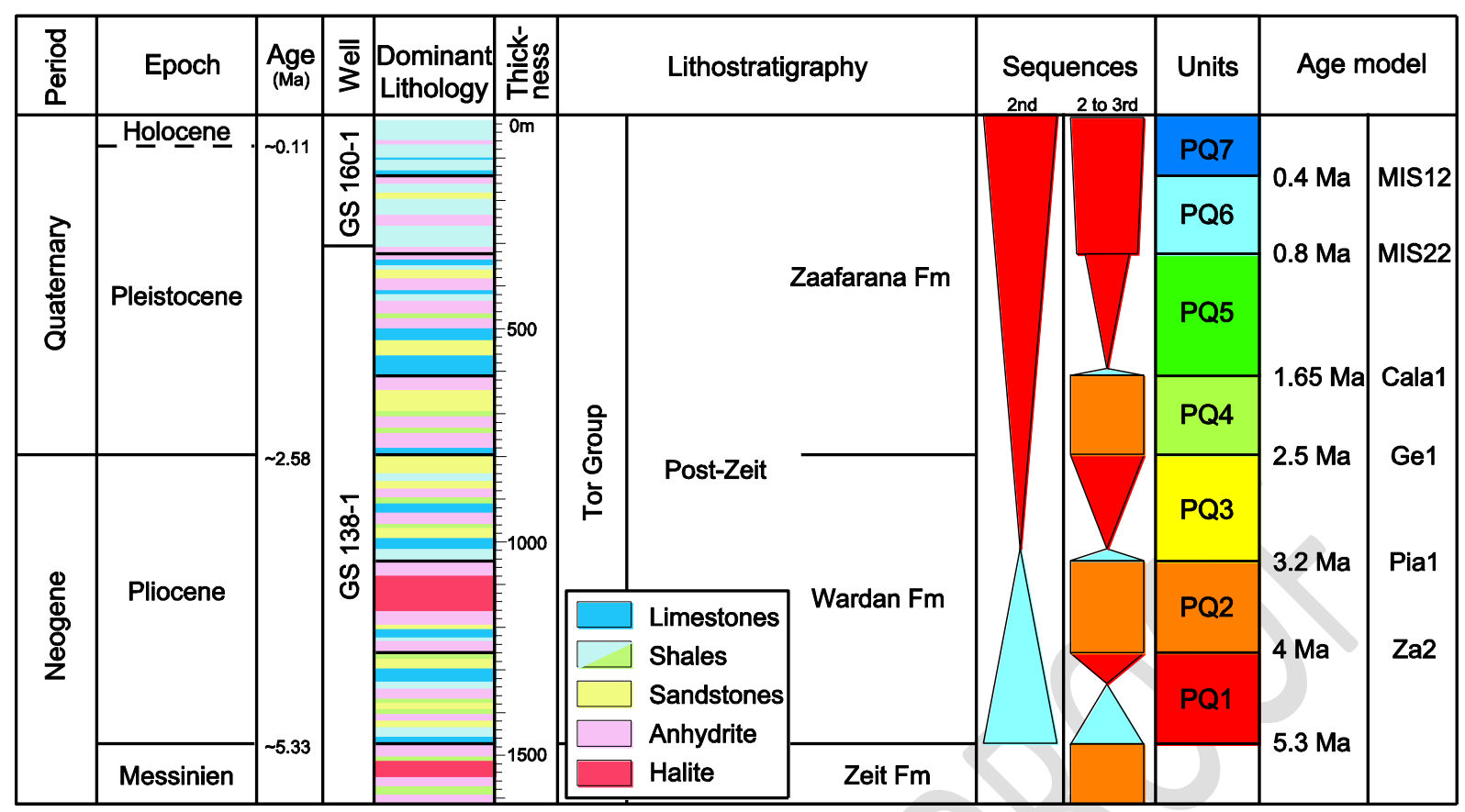

Figure 4 
Figure 5

$\underset{40}{\text { ⿴囗s }}$

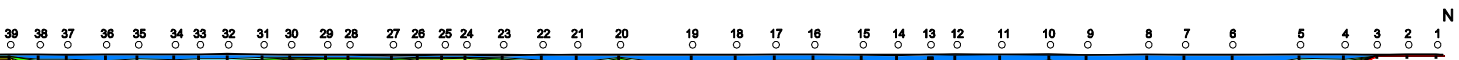
HEN1010

[B]

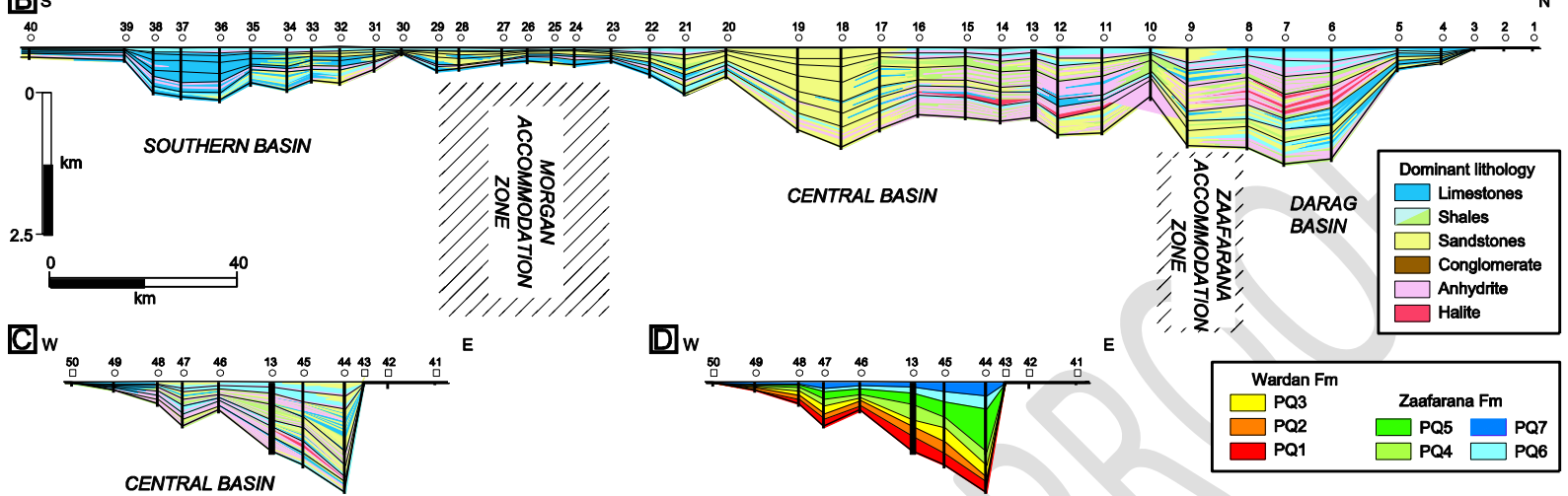


Figure 6

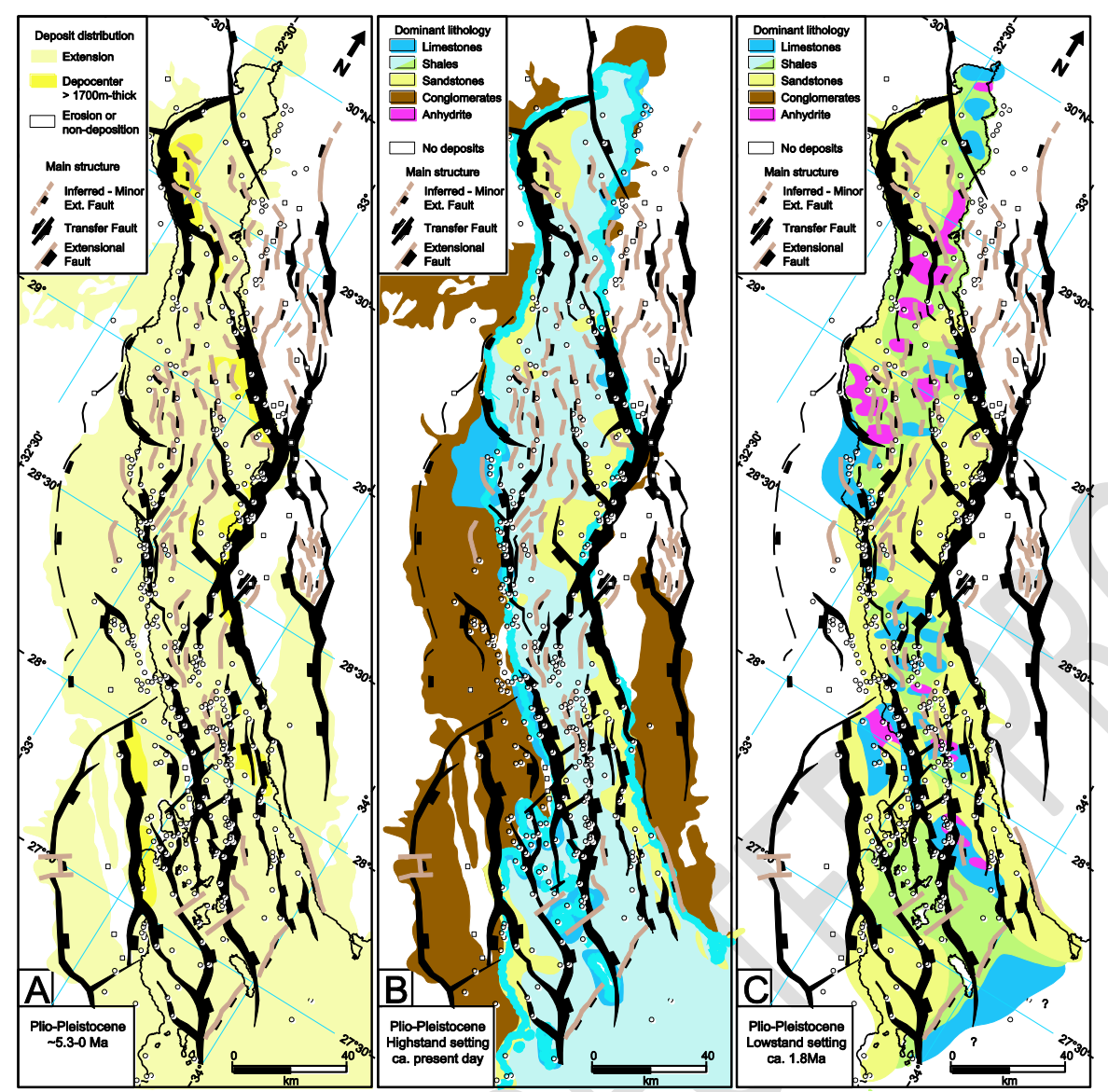


Figure7

\begin{tabular}{|c|c|c|c|c|c|c|c|}
\hline \multicolumn{2}{|c|}{$\begin{array}{l}\text { Chrono- } \\
\text { stratigraphy }\end{array}$} & \multirow[t]{2}{*}{ Formation } & \multirow[t]{2}{*}{ |Units } & \multirow[t]{2}{*}{$\begin{array}{c}\text { Global } \\
\text { Seatevel } \\
\text { curve }\end{array}$} & $\begin{array}{l}\text { Evaporite } \\
\text { accumulation rate } \\
\text { at rift scale } \\
\text { (m/Myr) }\end{array}$ & \multirow{2}{*}{\begin{tabular}{|c|c} 
Carbonate \\
accumulation rate \\
at rift scale \\
(m/Myr) \\
$50 \quad 100$ \\
5
\end{tabular}} & $\begin{array}{l}\text { Mean sediment supply } \\
\text { at rift scale } \\
\left(\mathrm{km}^{3} / \mathrm{Myr}\right)\end{array}$ \\
\hline 娄 总 & 惖 & & & & $100 \quad 200$ & & $\begin{array}{lll}500 & 1000 & 1500\end{array}$ \\
\hline 安 & 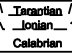 & Zaafarana & 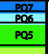 & & & 4 & $H$ \\
\hline$\frac{p^{2}}{2}$ & $\begin{array}{l}\text { Gelastan } \\
\end{array}$ & Post-_ & $\begin{array}{ll}\text { pas } \\
\text { pes }\end{array}$ & & & 5 & $\square$ \\
\hline & Piacenzian & $\begin{array}{l}\text { Zeit } \\
\text { Wardan }\end{array}$ & $\begin{array}{ll}022 \\
02\end{array}$ & & & & 二 \\
\hline & $\begin{array}{l}\text { Lanciaan } \\
\text { Messhlan }\end{array}$ & & & & & $\square$ & \\
\hline
\end{tabular}


Table1

\begin{tabular}{|c|c|c|c|c|c|c|c|c|c|c|c|c|c|}
\hline \multirow[t]{3}{*}{ Formation } & \multirow[t]{3}{*}{ Unit } & \multicolumn{2}{|c|}{ Estimated duration (Ma) } & \multirow{3}{*}{\begin{tabular}{|l|}
$\begin{array}{l}\text { Preserved } \\
\text { Volume at rift } \\
\text { scale }\end{array}$ \\
Km3 \\
\end{tabular}} & \multirow{2}{*}{\multicolumn{3}{|c|}{$\begin{array}{l}\text { Carbonate } \\
\text { accummulation rate } \\
\text { (m/Ma) } \\
\text { Porosity corrected }\end{array}$}} & \multirow{2}{*}{\multicolumn{3}{|c|}{$\begin{array}{l}\text { Evaporite accummulation } \\
\text { rate }(\mathrm{m} / \mathrm{Ma})\end{array}$}} & \multirow{2}{*}{\multicolumn{3}{|c|}{$\begin{array}{l}\text { Mean Sediment supply at } \\
\text { rift scale }(\mathrm{km} 3 / \mathrm{Ma}) \\
\text { Porosity corrected }\end{array}$}} \\
\hline & & \multirow{2}{*}{ Age (Ma) } & \multirow{2}{*}{ Duration (Ma) } & & & & & & & & & & \\
\hline & & & & & $\begin{array}{l}\text { Pref. } \\
\text { Prof }\end{array}$ & Max. & Min. & Pref. & Max. & Min. & Pref. & Max. & Min. \\
\hline \multirow[t]{4}{*}{ Zaafarana } & PQ7 & $0-0.4$ & 0.4 & 1164 & 55.0 & 56.5 & 44.8 & 83.2 & 260.7 & 18.7 & 942.9 & 1005.6 & 848.9 \\
\hline & PQ6 & $0.4-0.8$ & 0.4 & 994 & 55.8 & 60.3 & 43.8 & 82.9 & 235.0 & 15.9 & 820.4 & 859.1 & 751.4 \\
\hline & PQ5 & $0.8-1.65$ & 0.85 & 1938 & 78.2 & 80.9 & 76.6 & 86.9 & 124.3 & 38.8 & 738.7 & 781.2 & 702.0 \\
\hline & PQ4 & $1.65-2.5$ & 0.85 & 2497 & 59.4 & 66.1 & 46.8 & 112.0 & 243.8 & 72.3 & 881.4 & 1042.6 & 724.0 \\
\hline \multirow[t]{3}{*}{ Wardan } & PQ3 & $2.5-3.2$ & 0.7 & 1565 & 64.4 & 74.3 & 62.0 & 42.6 & 48.7 & 5.8 & 798.0 & 879.2 & 681.0 \\
\hline & PQ2 & $3.2-4$ & 0.8 & 1614 & 97.7 & 116.7 & 50.6 & 57.7 & 191.3 & 23.3 & 678.1 & 871.2 & 605.6 \\
\hline & PQ1 & $4-5.3$ & 1.3 & 3033 & 84.4 & 86.5 & 61.0 & 44.5 & 184.9 & 16.7 & 898.3 & 922.4 & 878.2 \\
\hline
\end{tabular}


Figure 8

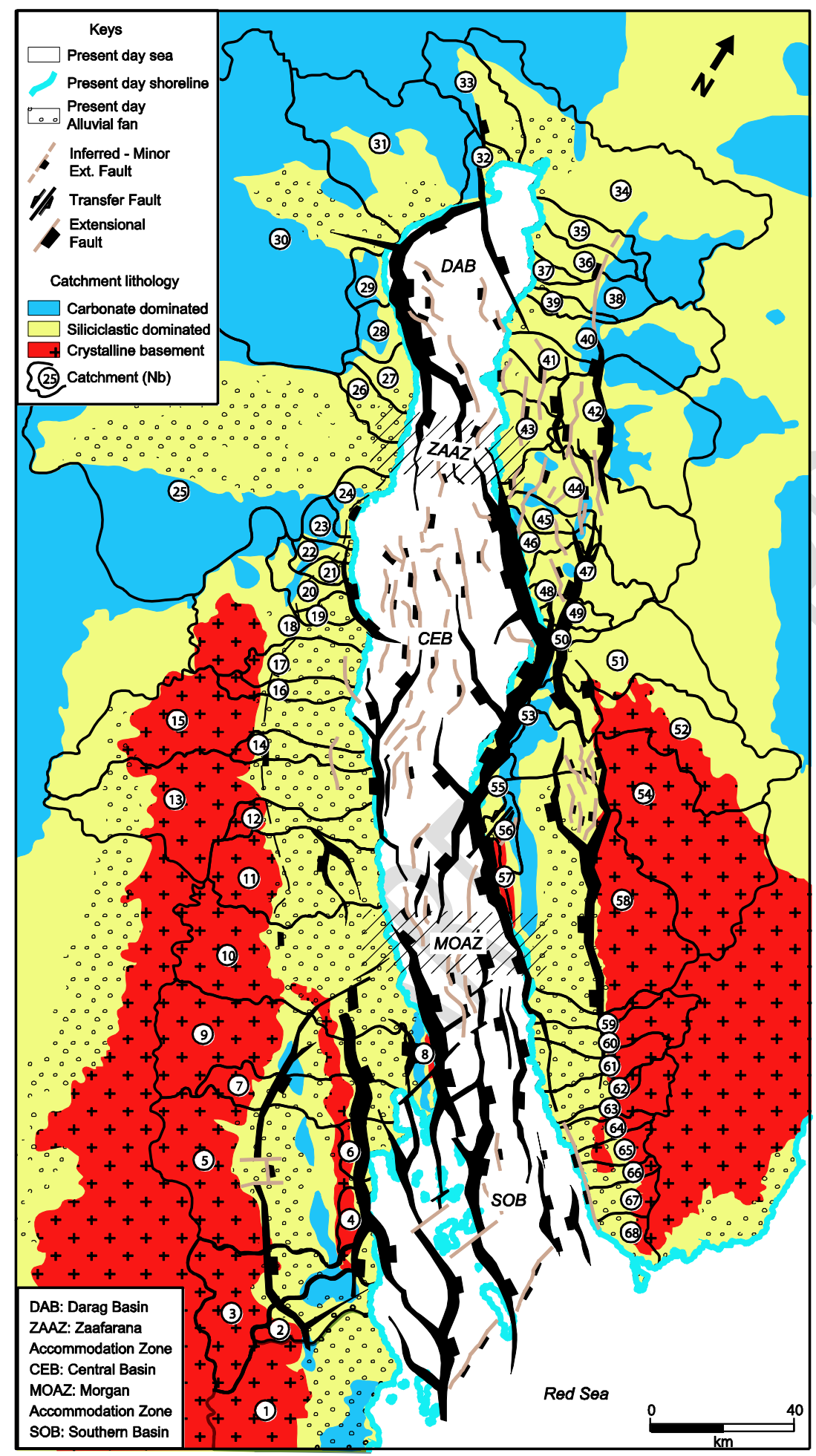


Figure9
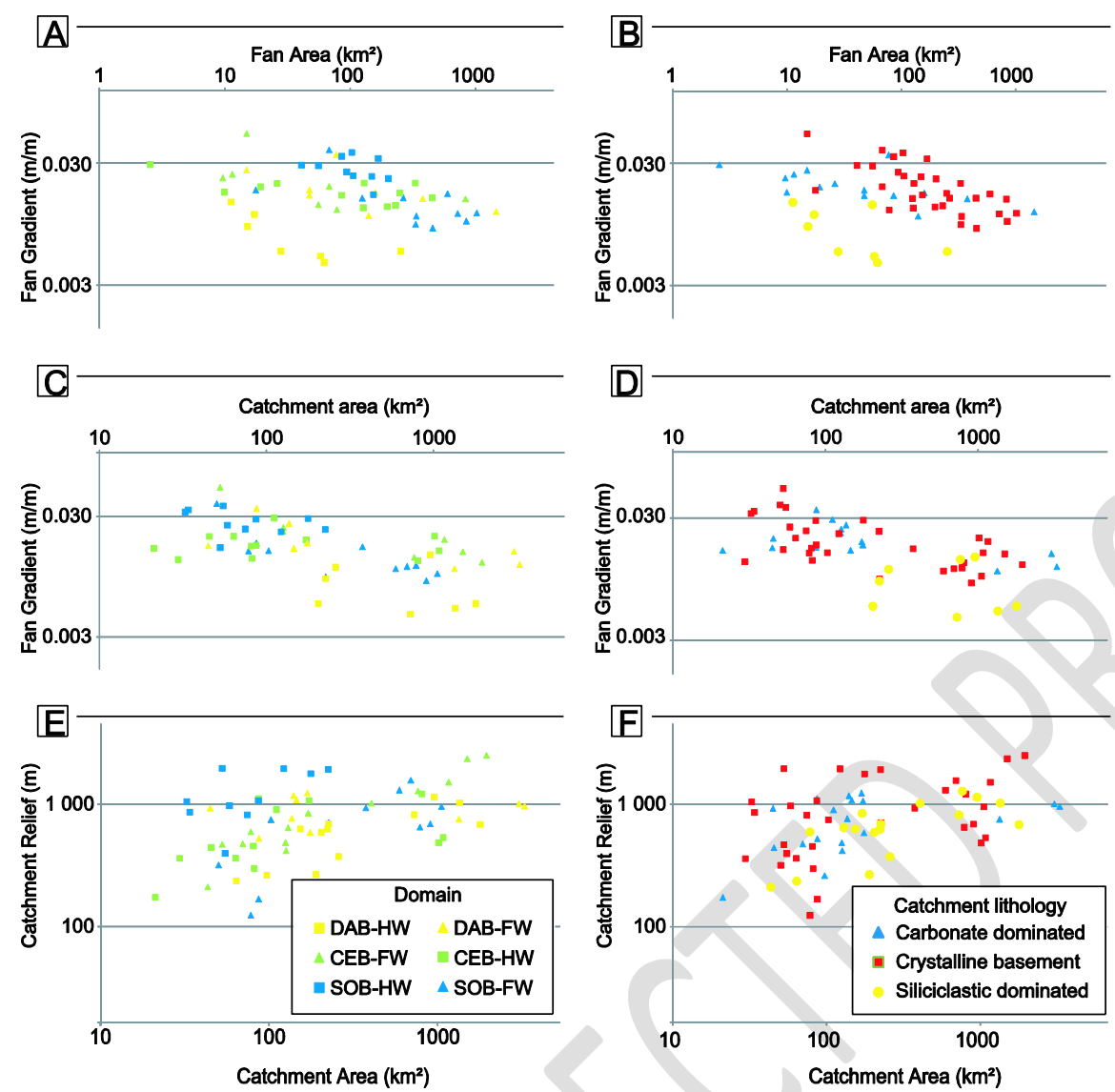
Figure 10

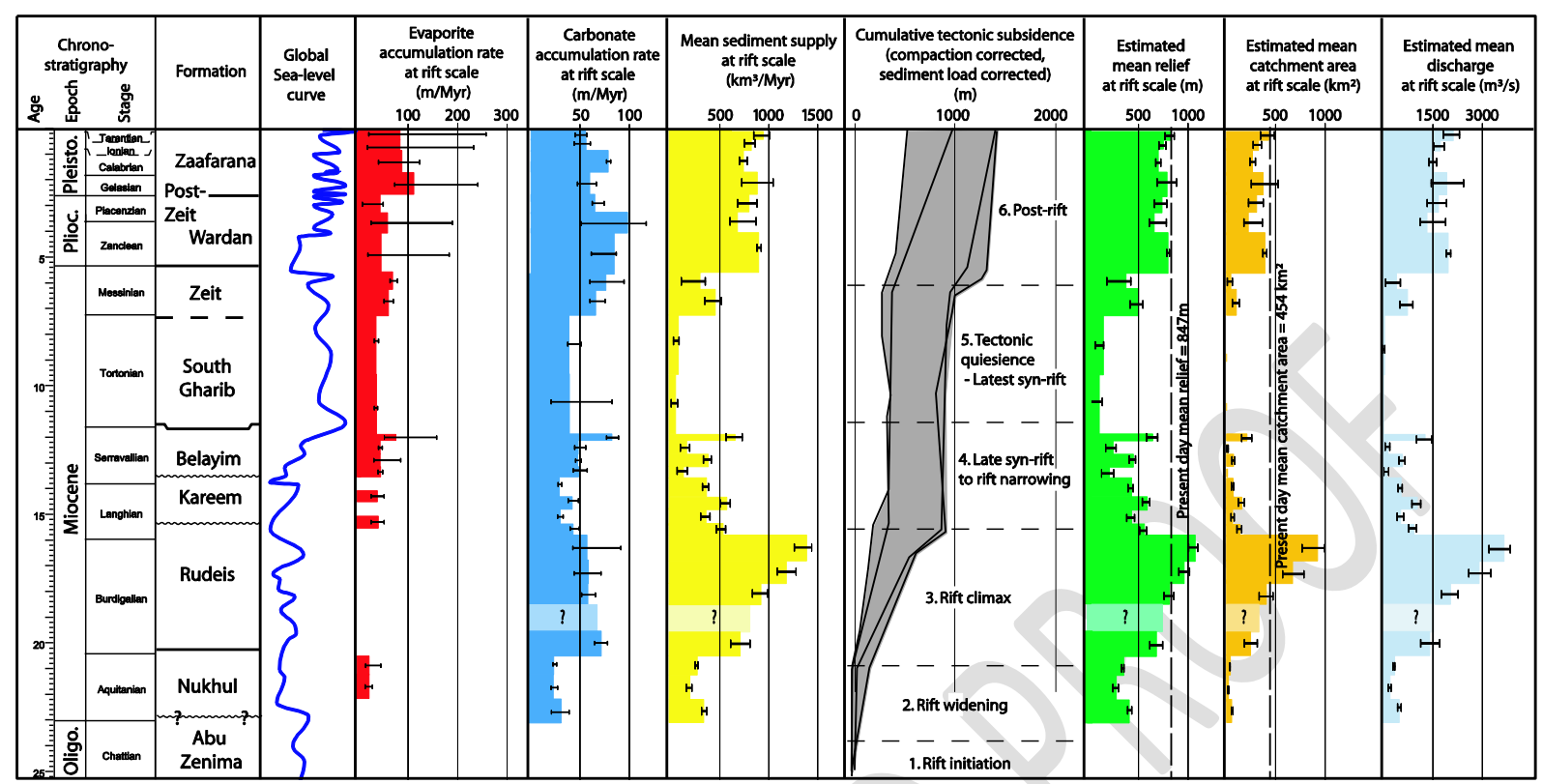


Table2

\begin{tabular}{|c|c|c|c|c|c|c|c|}
\hline \multicolumn{3}{|c|}{ Catchment } & & \multirow{2}{*}{$\begin{array}{l}\text { Fan } \\
\text { Fan gradient } \\
(\mathrm{m} / \mathrm{m})\end{array}$} & \multirow[b]{2}{*}{$\begin{array}{l}\text { Fan area } \\
(\mathrm{km} 2)\end{array}$} & \multirow[b]{2}{*}{ Type } & \multirow{2}{*}{\begin{tabular}{|l|} 
Setting \\
Tectonic \\
domain
\end{tabular}} \\
\hline $\mathrm{N}^{\circ}$ & $\begin{array}{l}\text { Relief } \\
(\mathrm{m})\end{array}$ & Area $(\mathrm{km} 2)$ & $\begin{array}{l}\text { Dominant lithology in the } \\
\text { catchment }\end{array}$ & & & & \\
\hline 1 & 1569 & 694.9 & Crystalline basement & 0.0115 & 721.3 & Bajada & SOB-FW \\
\hline 2 & 748 & 102.9 & Crystalline basement & 0.0156 & 265.5 & Bajada & SOB-FW \\
\hline 3 & 1304 & 594.5 & Crystalline basement & 0.0110 & 336.9 & Isolated & SOB-FW \\
\hline 4 & 168 & 87.1 & Crystalline basement & 0.0180 & 17.7 & Bajada & SOB-FW \\
\hline 5 & 956 & 1055.2 & Crystalline basement & 0.0100 & 845.6 & Bajada & SOB-FW \\
\hline 6 & 124 & 78.2 & Crystalline basement & 0.0154 & 125.1 & Bajada & SOB-FW \\
\hline 7 & 709 & 226.4 & Crystalline basement & 0.0095 & 333.1 & Bajada & SOB-FW \\
\hline 8 & 318 & 50.4 & Crystalline basement & 0.0384 & 68.1 & Bajada & SOB-FW \\
\hline 9 & 691 & 905.5 & Crystalline basement & 0.0088 & 455.0 & Bajada & SOB-FW \\
\hline 10 & 650 & 787.4 & Crystalline basement & 0.0117 & 1021.0 & Bajada & SOB-FW \\
\hline 11 & 934 & 375.8 & Crystalline basement & 0.0168 & 598.9 & Bajada & SOB-FW \\
\hline 12 & 298 & 82.0 & Crystalline basement & 0.0135 & 230.2 & Bajada & CEB-HW \\
\hline 13 & 533 & 1081.0 & Crystalline basement & 0.0156 & 451.0 & Bajada & CEB-HW \\
\hline 14 & 361 & 29.7 & Crystalline basement & 0.0132 & 197.6 & Bajada & CEB-HW \\
\hline 15 & 485 & 1015.0 & Crystalline basement & 0.0206 & 331.0 & Bajada & CEB-HW \\
\hline 16 & 362 & 63.6 & Crystalline basement & 0.0205 & 129.1 & Bajada & CEB-HW \\
\hline 17 & 455 & 81.0 & Crystalline basement & 0.0170 & 249.2 & Bajada & CEB-HW \\
\hline 18 & 1216 & 807.0 & Crystalline basement & 0.0129 & 127.3 & Bajada & CEB-HW \\
\hline 19 & 174 & 21.2 & Carbonate dominated & 0.0163 & 85.7 & Bajada & CEB-HW \\
\hline 20 & 1069 & 173.0 & Carbonate dominated & 0.0191 & 19.3 & Bajada & CEB-HW \\
\hline 21 & 442 & 45.5 & Carbonate dominated & 0.0204 & 26.2 & Bajada & CEB-HW \\
\hline 22 & 1114 & 86.8 & Carbonate dominated & 0.0173 & 9.9 & Bajada & CEB-HW \\
\hline 23 & 903 & 111.1 & Carbonate dominated & 0.0291 & 2.5 & Bajada & CEB-HW \\
\hline 24 & 524 & 87.3 & Carbonate dominated & 0.0350 & 77.4 & Bajada & DAB-FW \\
\hline 25 & 964 & 3289.7 & Carbonate dominated & 0.0120 & 1455.0 & Bajada & DAB-FW \\
\hline 26 & 929 & 44.9 & Carbonate dominated & 0.0171 & 159.1 & Bajada & DAB-FW \\
\hline 27 & 1083 & 146.1 & Carbonate dominated & 0.0163 & 47.3 & Bajada & DAB-FW \\
\hline 28 & 1241 & 169.2 & Carbonate dominated & & & & DAB-FW \\
\hline 29 & 1180 & 140.1 & Carbonate dominated & & & & DAB-FW \\
\hline 30 & 1011 & 3035.0 & Carbonate dominated & 0.0153 & 378.0 & Bajada & DAB-FW \\
\hline 31 & 756 & 1338.1 & Carbonate dominated & 0.0111 & 140.4 & Bajada & DAB-FW \\
\hline 32 & 765 & 136.6 & Carbonate dominated & 0.0263 & 15.0 & Bajada & DAB-FW \\
\hline 33 & 588 & 175.7 & Carbonate dominated & 0.0180 & 47.3 & Bajada & DAB-FW \\
\hline 34 & 683 & 1791.6 & Siliciclastic dominated & 0.0057 & 253.1 & Bajada & DAB-HW \\
\hline 35 & 625 & 223.0 & Carbonate dominated & & & & DAB-HW \\
\hline 36 & 590 & 204.8 & Carbonate dominated & 0.0057 & 28.1 & Bajada & DAB-HW \\
\hline 37 & 236 & 64.1 & Carbonate dominated & & & & DAB-HW \\
\hline 38 & 690 & 226.2 & Carbonate dominated & 0.0091 & 15.2 & Bajada & DAB-HW \\
\hline
\end{tabular}




\begin{tabular}{|c|c|c|c|c|c|c|c|}
\hline 39 & 262 & 97.3 & Carbonate dominated & & & & DAB-HW \\
\hline 40 & 822 & 728.7 & Carbonate dominated & 0.0046 & 62.1 & Bajada & DAB-HW \\
\hline 41 & 267 & 190.1 & Carbonate dominated & & & & DAB-HW \\
\hline 42 & 1024 & 1351.2 & Siliciclastic dominated & 0.0052 & 58.0 & Isolated & DAB-HW \\
\hline 43 & 374 & 259.3 & Carbonate dominated & 0.0114 & 17.3 & Bajada & DAB-HW \\
\hline 44 & 1145 & 956.1 & Siliciclastic dominated & 0.0144 & 11.2 & Isolated & DAB-HW \\
\hline 45 & 630 & 154.1 & Carbonate dominated & & & & DAB-HW \\
\hline 46 & 845 & 171.0 & Carbonate dominated & & & & CEB-FW \\
\hline 47 & 1021 & 406.1 & Siliciclastic dominated & & & & CEB-FW \\
\hline 48 & 211 & 43.5 & Siliciclastic dominated & & & & CEB-FW \\
\hline 49 & 644 & 130.0 & Siliciclastic dominated & & 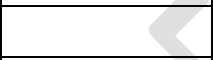 & & CEB-FW \\
\hline 50 & 596 & 78.2 & Siliciclastic dominated & & 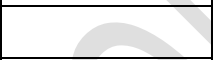 & 8 & CEB-FW \\
\hline 51 & 1282 & 767.2 & Siliciclastic dominated & 0.0137 & 55.8 & Isolated & CEB-FW \\
\hline 52 & 1517 & 1163.7 & Siliciclastic dominated & 0.0193 & 68.1 & Isolated & CEB-FW \\
\hline 53 & 476 & 70.1 & Carbonate dominated & & + & P & CEB-FW \\
\hline 54 & 2511 & 1951.4 & Crystalline basement & 0.0125 & 78.4 & Isolated & CEB-FW \\
\hline 55 & 486 & 125.8 & Carbonate dominated & 0.0226 & 9.6 & Bajada & CEB-FW \\
\hline 56 & 418 & 126.5 & Carbonate dominated & 0.0243 & 11.5 & Bajada & CEB-FW \\
\hline 57 & 469 & 52.9 & Crystalline basement & 0.0522 & 15.0 & Bajada & CEB-FW \\
\hline 58 & 2360 & 1499.7 & Crystalline basement & 0.0153 & 833.4 & Bajada & CEB-FW \\
\hline 59 & 1963 & 52.9 & Crystalline basement & 0.0165 & 153.5 & Bajada & SOB-HW \\
\hline 60 & 1928 & 224.8 & Crystalline basement & 0.0233 & 148.8 & Bajada & SOB-HW \\
\hline 61 & 1959 & 122.5 & Crystalline basement & 0.0223 & 201.6 & Bajada & SOB-HW \\
\hline 62 & 1051 & 32.6 & Crystalline basement & 0.0326 & 167.6 & Bajada & SOB-HW \\
\hline 63 & 1776 & 177.2 & Crystalline basement & 0.0288 & 40.9 & Bajada & SOB-HW \\
\hline 64 & 973 & 58.4 & Crystalline basement & 0.0253 & 93.9 & Bajada & SOB-HW \\
\hline 65 & 1074 & 86.6 & Crystalline basement & 0.0285 & 55.9 & Bajada & SOB-HW \\
\hline 66 & 861 & 34.0 & Crystalline basement & 0.0340 & 85.7 & Bajada & SOB-HW \\
\hline 67 & 818 & 74.6 & Crystalline basement & 0.0236 & 105.6 & Bajada & SOB-HW \\
\hline 68 & 397 & 55.2 & Crystalline basement & 0.0366 & 103.4 & Bajada & SOB-HW \\
\hline
\end{tabular}


Table 3

a. Fan gradient ( $G f, m / m)$ versus Fan area (Af, $k m 2)$

\begin{tabular}{llll}
\hline & $\alpha 3$ & $\alpha 4$ & $r 2$ \\
Southern Basin - SOB & & & \\
Footwall - FW & 0.046 & -0.214 & 0.3924 \\
Hangingwall - HW & 0.0626 & -0.185 & 0.1518 \\
Central Basin - CEB & & & \\
Footwall - FW & 0.041 & -0.184 & 0.3461 \\
Hangingwall - HW & 0.0262 & -0.094 & 0.408 \\
Darag Basin - DAB & & & \\
Footwall - FW & 0.0386 & -0.165 & 0.3678 \\
Hangingwall - HW & 0.0218 & -0.304 & 0.5648 \\
Carbonate basement & 0.0307 & -0.125 & 0.4256 \\
Crystalline basement & 0.0799 & -0.286 & 0.4511 \\
Siliciclastic basement & 0.0207 & -0.263 & 0.3347 \\
& & & \\
b. Fan gradient (Gf, m/m) versus Catchment area (A, km2) & \multicolumn{3}{c}{$\alpha 6$}
\end{tabular}

Southern Basin - SOB

\begin{tabular}{lccc} 
Footwall - FW & 0.0701 & -0.288 & 0.6032 \\
Hangingwall - HW & 0.0434 & -0.114 & 0.0974 \\
Central Basin - CEB & & & \\
Footwall - FW & 0.1202 & -0.94 & 0.7723 \\
Hangingwall - HW & 0.018 & -0.006 & 0.0012 \\
Darag Basin - DAB & & & \\
Footwall - FW & 0.0429 & -0.152 & 0.4483 \\
Hangingwall - HW & 0.0169 & -0.0169 & 0.0727 \\
& & & \\
c. Catchment relief (R, m) versus Catchment area & $(\mathrm{A}, \mathrm{km} 2)$ \\
\hline & $\alpha 7$ & $\alpha 8$ & $\mathrm{r} 2$ \\
Southern Basin - SOB & & & \\
Footwall - FW & 28.502 & 0.536 & 0.5558 \\
Hangingwall - HW & 170.21 & 0.4419 & 0.3098 \\
Central Basin - CEB & & & \\
Footwall - FW & 46.426 & 0.5182 & 0.9016 \\
Hangingwall - HW & 173.43 & 0.2294 & 0.2645 \\
Darag Basin - DAB & & & \\
Footwall - FW & 740.07 & 0.029 & 0.0233 \\
Hangingwall - HW & 55.696 & 0.3966 & 0.6081 \\
Carbonate basement & 82.309 & 0.358 & 0.5026 \\
Crystalline basement & 220.29 & 0.239 & 0.1798 \\
Siliciclastic basement & 257.05 & 0.1896 & 0.2129
\end{tabular}


Table 4

\begin{tabular}{|c|c|c|c|c|c|c|c|c|c|c|c|c|c|c|c|c|}
\hline \multirow[t]{3}{*}{ Formation } & \multirow[t]{3}{*}{ Interval } & \multirow[t]{3}{*}{ Figure } & \multicolumn{2}{|c|}{ Estimated duration (Ma) } & \multirow{2}{*}{\multicolumn{3}{|c|}{$\begin{array}{l}\text { Mean discharge } \\
\text { at rift scale (m3/s) }\end{array}$}} & \multirow{2}{*}{\multicolumn{3}{|c|}{$\begin{array}{l}\text { Mean catchment size } \\
\text { at rift scale (km2) }\end{array}$}} & \multirow{2}{*}{\multicolumn{3}{|c|}{$\begin{array}{l}\text { Mean Relief } \\
\text { at rift scale (m) }\end{array}$}} & \multicolumn{3}{|c|}{$\begin{array}{l}\text { Mean Sediment supply at } \\
\text { rift scale (km3/Myr) }\end{array}$} \\
\hline & & & \multirow[t]{2}{*}{ Age (Ma) } & \multirow[t]{2}{*}{ Duration $(\mathrm{Ma})$} & & & & & & & & & & & & \\
\hline & & & & & \begin{tabular}{|l} 
Pref. \\
\end{tabular} & Max. & Min. & Pref. & Max. & Min. & Pref. & Max. & Min. & Pref. & Max. & Min. \\
\hline \multirow[t]{4}{*}{ Zaafarana } & PQ7 & PQ7 & $0-0.4$ & 0.4 & 2136 & 2337 & 1844 & 432 & 491 & 350 & 833 & 870 & 777 & 942.9 & 1005.6 & 848.9 \\
\hline & PQ6 & PQ6 & $0.4-0.8$ & 0.4 & 1758 & 1875 & 1554 & 327 & 358 & 274 & 759 & 783 & 716 & 820.4 & 859.1 & 751.4 \\
\hline & PQ5 & $\mathrm{PQ5}$ & $0.8-1.65$ & 0.85 & 1518 & 1641 & 1413 & 265 & 296 & 239 & 708 & 735 & 684 & 738.7 & 781.2 & 702 \\
\hline & $\mathrm{PQ4}$ & PQ4 & $1.65-2.5$ & 0.85 & 1943 & 2459 & 1476 & 377 & 528 & 254 & 796 & 891 & 699 & 881.4 & 1042.6 & 724 \\
\hline \multirow[t]{3}{*}{ Wardan } & $\mathrm{PQ3}$ & PQ3 & $2.5-3.2$ & 0.7 & 1691 & \begin{tabular}{|l|}
1937 \\
\end{tabular} & 1354 & 308 & 375 & 225 & 745 & 795 & 671 & 798 & 879.2 & 681 \\
\hline & $\overline{P Q 2}$ & $\mathrm{PQ} 2$ & $3.2-4$ & 0.8 & 1346 & 1912 & 1149 & 223 & 368 & 178 & 669 & 790 & 620 & 678.1 & 871.2 & 605.6 \\
\hline & PQ1 & PQ1 & $4-5.3$ & 1.3 & 1996 & 2071 & 1933 & 392 & 413 & 374 & 807 & 821 & 794 & 898.3 & 922.4 & 878.2 \\
\hline \multirow[t]{2}{*}{ Zeit } & Zeit Upper & $6 s$ & $5.3-6.2$ & 0.9 & 423 & 546 & 104 & 43 & 61 & 6 & 385 & 435 & 197 & 296.4 & 355.8 & 108.7 \\
\hline & Zeit Lower & $6 r$ & $6.2-7.2$ & 1 & 764 & 918 & 527 & 99 & 129 & 59 & 511 & 557 & 428 & 452.6 & 515.9 & 347.2 \\
\hline \multirow{6}{*}{\begin{tabular}{|l|}
$\begin{array}{l}\text { South } \\
\text { Gharib }\end{array}$ \\
Belayim \\
\end{tabular}} & South Gharib Upper & $6 q$ & $7.2-9.5$ & 2.3 & 67 & 71 & 15 & 3 & 3 & 0 & 161 & 165 & 79 & 79.8 & 82.9 & 27.6 \\
\hline & South Gharib Lower & $6 p$ & $9.5-11.8$ & 2.3 & 37 & 57 & 2 & 1 & 2 & 0 & 120 & 149 & 27 & 51.5 & 71.0 & 5.5 \\
\hline & Belayim-B1 Hammam Faraun & 60 & $11.8-12.1$ & 0.3 & 1289 & 1495 & 1042 & 210 & 259 & 155 & 655 & 703 & 592 & 657.4 & 730.9 & 564.8 \\
\hline & Belayim-B2 Feiran & $6 n$ & $12.1-12.6$ & 0.5 & 181 & 229 & 89 & 13 & 18 & 5 & 257 & 288 & 184 & 161.5 & 191.2 & 97.5 \\
\hline & \begin{tabular}{|l} 
Belayim-B3 Sidri \\
\end{tabular} & $6 \mathrm{~m}$ & $12.6-13.1$ & 0.5 & 612 & 680 & 504 & 72 & 84 & 55 & 459 & 483 & 419 & 386.2 & 416.1 & 336.1 \\
\hline & Belayim-B4 Baba & 61 & $13.1-13.6$ & 0.5 & 133 & 192 & 52 & 8 & 14 & 2 & 222 & 265 & 142 & 130.1 & 168.7 & 66.7 \\
\hline \multirow[t]{4}{*}{ Kareem } & Kareem-K1 top Shagar & $6 \mathrm{k}$ & $13.6-14.3$ & 0.7 & 568 & 608 & 480 & 65 & 72 & 51 & 443 & 458 & 409 & 366.0 & 384.5 & 324.7 \\
\hline & Kareem-K2/K1 Markha/Shagar & $6 \mathrm{j}$ & $14.3-14.8$ & 0.5 & 1058 & 1161 & 888 & 158 & 181 & 123 & 596 & 623 & 549 & 570.8 & 610.1 & 503.9 \\
\hline & Kareem-K2 middle Markha & $6 i$ & $14.8-15.3$ & 0.7 & 559 & 647 & 445 & 64 & 78 & 46 & 440 & 472 & 395 & 361.9 & 401.6 & 307.6 \\
\hline & Kareem-K2 base Markha & $6 \mathrm{~h}$ & 15.3-15.8 & 0.5 & 959 & 1036 & 797 & 138 & 154 & 106 & 569 & 590 & 521 & 532.3 & 562.3 & 466.2 \\
\hline \multirow[t]{4}{*}{ Rudeis } & Rudeis-R1 & $6 \mathrm{~g}$ & $15.8-16.7$ & 0.9 & 3671 & 3863 & 3219 & 936 & 1006 & 776 & 1078 & 1105 & 1013 & 1388.4 & 1439.8 & 1263.9 \\
\hline & Rudeis-R2 & $6 f$ & $16.7-17.6$ & 0.9 & 2924 & 3276 & 2609 & 676 & 795 & 575 & 967 & 1021 & 916 & 1180.0 & 1279.9 & 1087.9 \\
\hline & Rudeis-R3 & $6 e$ & $17.6-18.5$ & 0.9 & 2061 & 2293 & 1792 & 410 & 478 & 336 & 819 & 862 & 766 & 919.2 & 991.9 & 831.9 \\
\hline & Rudeis-R5 & $6 \mathrm{~d}$ & $19.6-20.4$ & 0.8 & 1439 & 1726 & 1166 & 245 & 318 & 182 & 690 & 753 & 624 & 711.0 & 809.9 & 611.9 \\
\hline \multirow[t]{3}{*}{ Nukhul } & Nukhul-Nu1 & $6 c$ & $20.4-21.2$ & 0.8 & 372 & 383 & 328 & 36 & 37 & 30 & 362 & 367 & 341 & 270.6 & 276.2 & 247.4 \\
\hline & Nukhul-Nu2 & $6 \mathrm{~b}$ & $21.2-22.1$ & 0.9 & 236 & 270 & 179 & 19 & 23 & 13 & 292 & 311 & 256 & 195.7 & 215.3 & 160.5 \\
\hline & Nukhul-Nu3 top Shoab Ali Mb. & $6 a$ & $22.1-23$ & 0.9 & 507 & 568 & 459 & 55 & 65 & 48 & 420 & 443 & 401 & 337.7 & 366.1 & 314.4 \\
\hline
\end{tabular}

